\title{
Development of Crystalline Ceramics for Immobilization of Advanced Fuel Cycle Reprocessing Wastes
}

Fuel Cycle Research \& Development

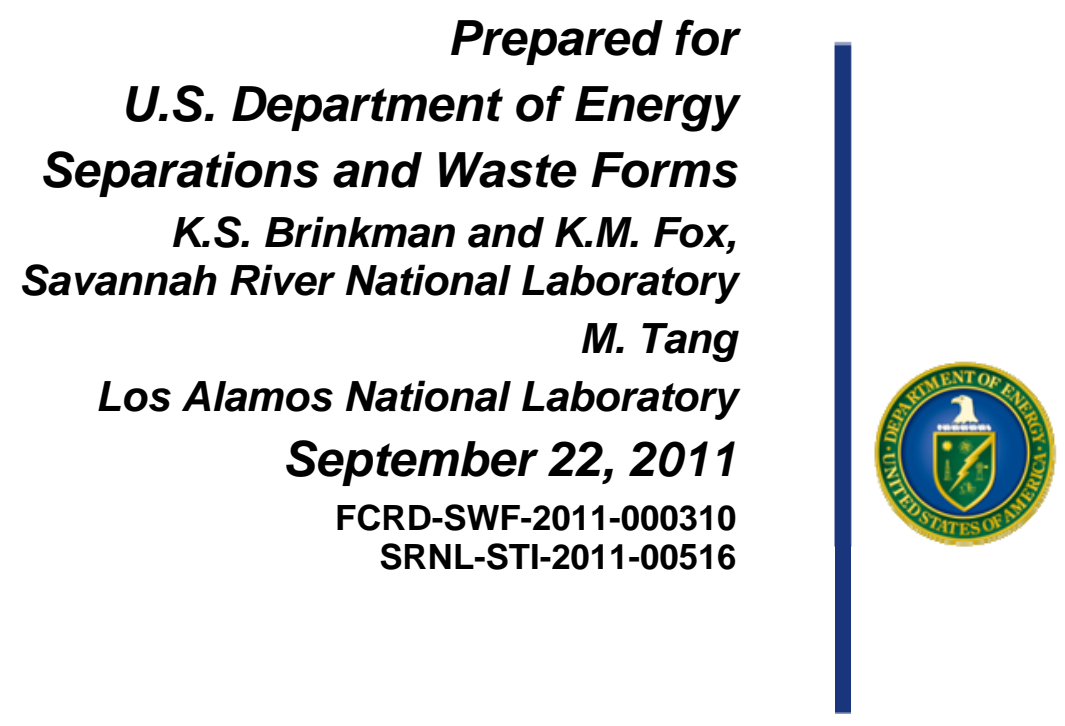




\section{DISCLAIMER}

This information was prepared as an account of work sponsored by an agency of the U.S. Government. Neither the U.S. Government nor any agency thereof, nor any of their employees, makes any warranty, expressed or implied, or assumes any legal liability or responsibility for the accuracy, completeness, or usefulness, of any information, apparatus, product, or process disclosed, or represents that its use would not infringe privately owned rights. References herein to any specific commercial product, process, or service by trade name, trade mark, manufacturer, or otherwise, does not necessarily constitute or imply its endorsement, recommendation, or favoring by the U.S. Government or any agency thereof. The views and opinions of authors expressed herein do not necessarily state or reflect those of the U.S. Government or any agency thereof. 


\section{APPROVALS}

\section{AUTHORS:}

K.S. Brinkman

Date

SRNL Materials Science and Technology

K.M. Fox

Date

SRNL Process Technology Programs

REVIEWERS:

D. K. Peeler, Technical Reviewer

Date

SRNL Process Technology Programs

T. M. Adams, Management Reviewer

Date

Manager, SRNL Materials Science and Technology

C.C. Herman, Management Reviewer

Date

Manager, SRNL Process Technology Programs

S.L. Marra, Management Reviewer

Date

Manager, SRNL Environmental and Chemical Process Technology Research Programs 


\section{SUMMARY}

The Savannah River National Laboratory (SRNL) is developing crystalline ceramic waste forms to incorporate CS/LN/TM high Mo waste streams consisting of perovskite, hollandite, pyrochlore, zirconolite, and powellite phase assemblages. Simple raw materials, including $\mathrm{Al}_{2} \mathrm{O}_{3}, \mathrm{CaO}$, and $\mathrm{TiO}_{2}$ were combined with simulated waste components to produce multiphase crystalline ceramics. Fiscal Year 2011 (FY11) activities included i) expanding the compositional range by varying waste loading and fabrication of compositions rich in $\mathrm{TiO}_{2}$, ii) exploring the processing parameters of ceramics produced by the melt and crystallize process, iii) synthesis and characterization of select individual phases of powellite and hollandite that are the target hosts for radionuclides of Mo, Cs, and Rb, and iv) evaluating the durability and radiation stability of single and multi-phase ceramic waste forms.

Two fabrication methods, including melting and crystallizing, and pressing and sintering, were used with the intent of studying phase evolution under various sintering conditions. An analysis of the XRD and SEM/EDS results indicates that the targeted crystalline phases of the FY11 compositions consisting of pyrochlore, perovskite, hollandite, zirconolite, and powellite were formed by both press and sinter and melt and crystallize processing methods. An evaluation of crystalline phase formation versus melt processing conditions revealed that hollandite, perovskite, zirconolite, and residual $\mathrm{TiO}_{2}$ phases formed regardless of cooling rate, demonstrating the robust nature of this process for crystalline phase development.

The multiphase ceramic composition CSLNTM-06 demonstrated good resistance to proton beam irradiation. Electron irradiation studies on the single phase $\mathrm{CaMoO}_{4}$ (a component of the multiphase waste form) suggested that this material exhibits stability to 1000 years at anticipated self-irradiation doses $\left(2 \times 10^{10}-2 \times 10^{11} \mathrm{~Gy}\right)$, but that its stability may be rate dependent, therefore limiting the activity of the waste for which it can be employed. Overall, these preliminary results indicate good radiation damage tolerance for the crystalline ceramic materials.

The PCT results showed that, for all of the waste forms tested, the normalized release values for most of the elements measured, including all of the lanthanides and noble metals, were either very small or below the instrument detection limits. Elevated normalized release values were measured only for Cs, Mo, and $\mathrm{Rb}$. It is difficult to draw further conclusions from these data until a benchmark material is developed for the PCT with this type of waste form. Calcined, simulated CS/LN/TM High Mo waste without additives had relatively low normalized release values for $\mathrm{Cs}$, Mo, and Rb. A review of the chemical composition data for this sample showed that these elements were well retained after the calcination. Therefore, it will be useful to further characterize the calcined material to determine what form these elements are in after calcining. This, along with single phase studies on Cs containing crystal structures such as hollandite, should provide insight into the most ideal phases to incorporate these elements to produce a durable waste form. 


\section{CONTENTS}

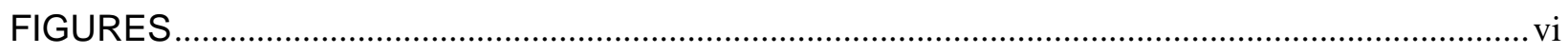

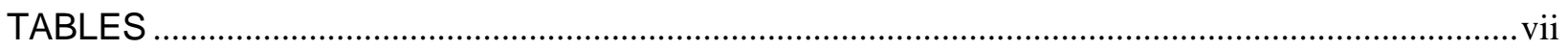

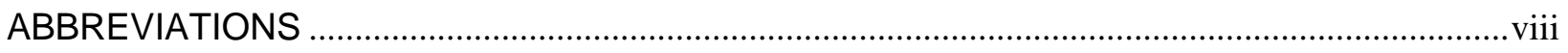

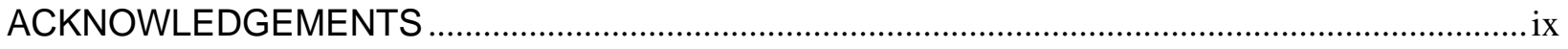

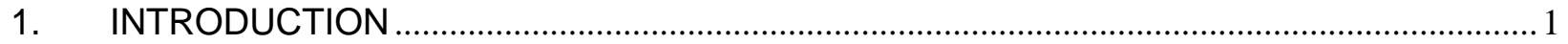

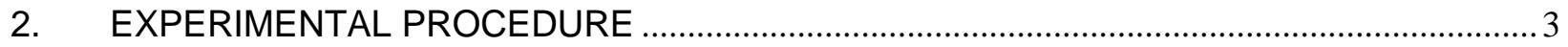

2.1. Projected Waste Stream Compositions............................................................................. 3

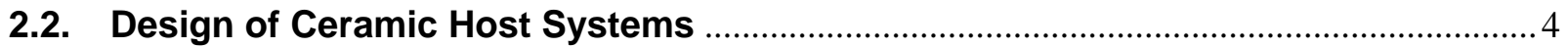

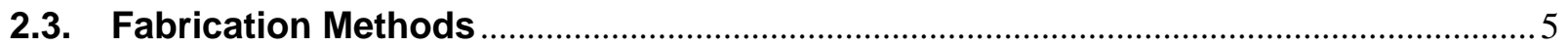

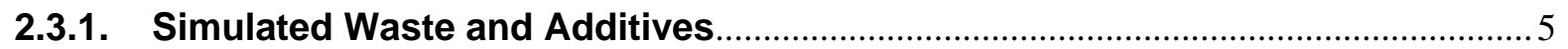

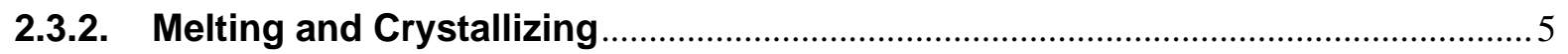

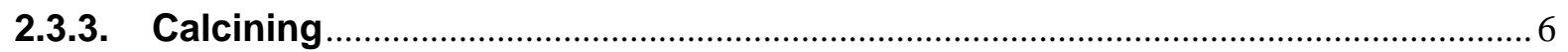

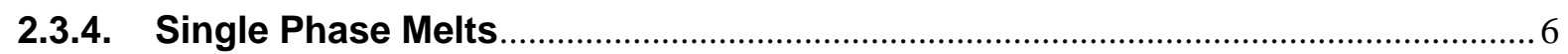

2.3.5. Cold Pressing and Sintering for Extended Periods ............................................. 7

2.4. Characterization of Crystalline Waste Forms ............................................................... 7

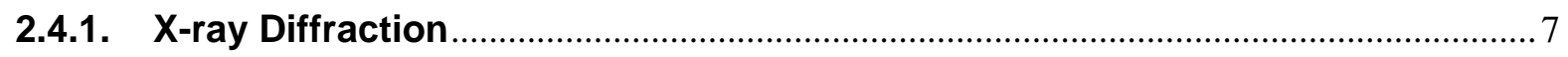

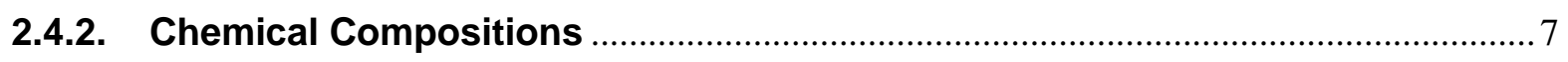

2.4.3. Electron Microscopy and Elemental Analysis ................................................... 7

2.4.4. Chemical Durability ............................................................................................. 7

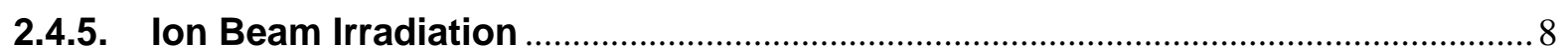

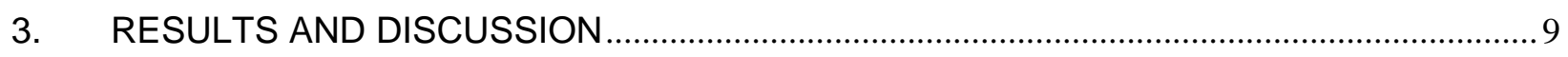

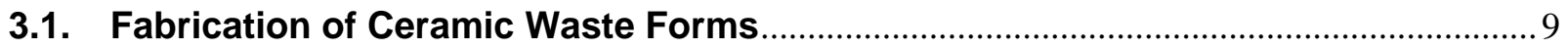

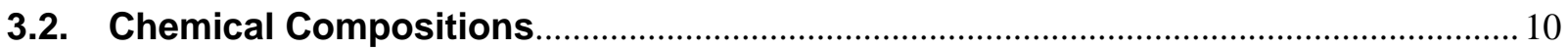

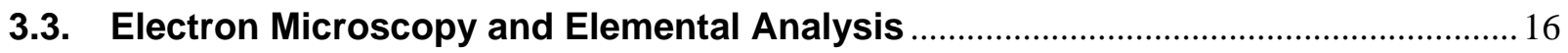

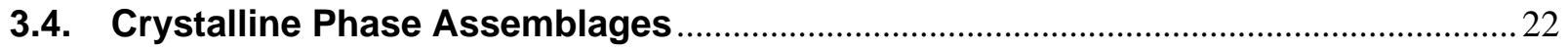

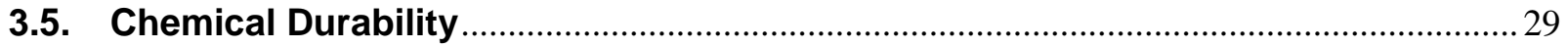

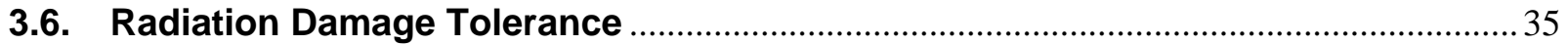

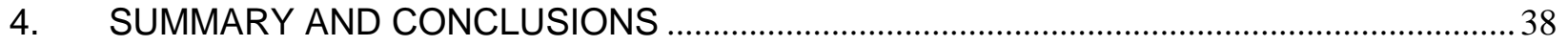

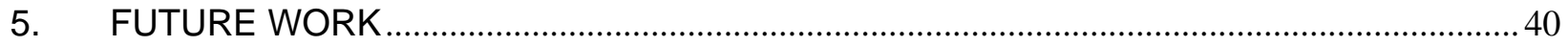

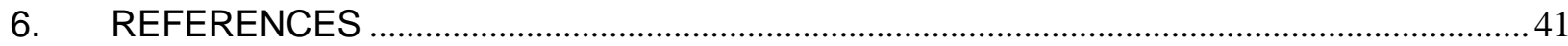




\section{FIGURES}

Figure 2-1. Furnace Cooling Profile for the Melt and Crystallize Fabrication Method.... 6

Figure 3-1. Photographs of the CS/LN/TM High Mo Waste Forms after Melting and Crystallizing in $\mathrm{Pt} / \mathrm{Rh}$ Crucibles. . .9

Figure 3-2. Photograph of Composition CSLNTM-11 after Melting at $1500{ }^{\circ} \mathrm{C}$ for 6 Hours and Crystallizing....... 10

Figure 3-3. Backscattered Electron Micrograph of a Polished Surface of Composition CSLNTM-06 Fabricated by Melting and Crystallizing. 16

Figure 3-4. EDS Mapping for Select Elements in Composition CSLNTM-06 Fabricated by Melting and Crystallizing. 17

Figure 3-5. Backscattered Electron Micrograph of a Polished Surface of Composition CSLNTM-10 Fabricated by Melting and Crystallizing.

Figure 3-6. EDS Mapping for Select Elements in Composition CSLNTM-10 Fabricated by Melting and Crystallizing. 19

Figure 3-7. Secondary Electron Micrographs of a Sample of Composition CSLNTM-10 Prepared by FIB Milling Before (a) and After (b) Leach in Water. 20

Figure 3-8. EDS Mapping for Select Elements in a FIB Milled Sample of Composition CSLNTM-10 Fabricated by Melting and Crystallizing, Prior to Leaching in Water.

Figure 3-9. EDS Mapping for Select Elements in a FIB Milled Sample of Composition CSLNTM-10 Fabricated by Melting and Crystallizing, After Leaching in Water.

Figure 3-10. XRD Patterns of Calcined Powders Heated to $1000{ }^{\circ} \mathrm{C}$ (black line) and a Melted and Crystallized Sample (red line) Targeting $\mathrm{BaAl}_{2} \mathrm{Ti}_{6} \mathrm{O}_{16}$ Single Phase Formation................................ 27

Figure 3-11. XRD of melt and crystallize $1500^{\circ} \mathrm{C}$ process targeting $\mathrm{CaMoO}_{4}$ single phase ................... 28

Figure 3-12. TEM Image of a $\mathrm{CaMoO}_{4}$ Sample Produced by Melting and Crystalizing, Along with a Selected Area Electron Diffraction Image and an EDS spectrum.

Figure 3-13. XRD Patterns for Composition CSLNTM-06 Prior to (Pristine) and After $2 \mathrm{MeV}$ proton irradiation at a fluence of $4 \times 10^{17}$ ions $/ \mathrm{cm}^{2}$ (equivalent to a dose of $3 \times 10^{9} \mathrm{~Gy}$ ). 35

Figure 3-14. High-Resolution TEM Images Reveal Little Change to the Crystalline Structure of the

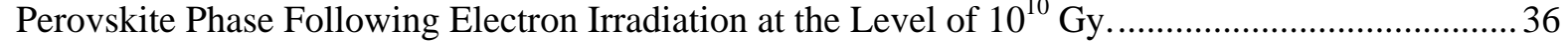

Figure 3-15. High-Resolution TEM Images Show the Microstructural Evolution of a $\mathrm{CaMoO}_{4} \mathrm{Sample}$ Under Electron Irradiation at Increasing Doses. 


\section{TABLES}

Table 2-1. Projected Waste Stream Compositions (wt \%) for Waste Form Development. ${ }^{14,15}$.................. 4

Table 2-2. Targeted Compositions (wt \%) for the CS/LN/TM High Mo Ceramic Waste Forms................ 5

Table 2-3. Targeted Compositions (wt \%) of Selected CS/LN/TM High Mo Ceramic Waste Forms from

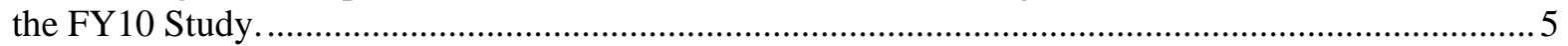

Table 3-1. Targeted and Measured Compositions (wt \%) of the Ceramic Waste Forms Fabricated by Melting and Crystallizing. 11

Table 3-2. Targeted and Measured Compositions (wt \%) of the Composition CSLNTM-11 Ceramic Waste Form as a Function of Heat Treatment. .................................................................................. 12

Table 3-3. Targeted and Measured Compositions (wt \%) of Additional Ceramic Waste Forms and the Simulated, Calcined Waste Material. .................................................................................................... 14

Table 3-4. Targeted and Measured Compositions (wt \%) of the Single Phase Samples Fabricated by Melting and Crystallizing. ..... 15

Table 3-5. Summary of XRD Data for Ceramic Waste Forms Prepared by Press and Sinter, and Melt and

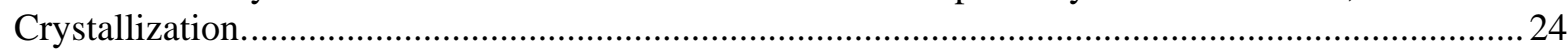

Table 3-6. Summary of FY10 and FY11 XRD Data for CS/LN/TM High Mo Waste Forms Prepared by a Melt and Crystallize Process. ............................................................................................................. 26

Table 3-7. Results of BET Surface Area Measurements for Those Samples Included in the PCTs.......... 30

Table 3-8. Results of the PCT for the First Set of Ceramic Waste Forms. Normalized Release Values

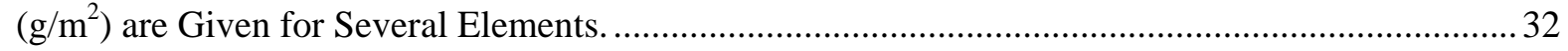

Table 3-9. Results of the PCT for the Second Set of Ceramic Waste Forms. Normalized Release Values $\left(\mathrm{g} / \mathrm{m}^{2}\right)$ are Given for Several Elements........................................................................................... 34 


\section{ABBREVIATIONS}

AFCI

ARM

BET

CCIM

CS

DOE

EA

EDS

FCR\&D

FIB

HLW

ICP-AES

ICP-MS

LANL

LN

NM

PCT

PNNL

Redox

SEM

SPS

SRNL

TALSPEAK

TEM

$\mathrm{TM}$

TRUEX

XRD
Advanced Fuel Cycle Initiative

Approved Reference Material

Brunauer-Emmett-Teller

Cold Crucible Induction Melter

Cesium/Strontium

Department of Energy

Environmental Assessment

Energy Dispersive Spectroscopy

Fuel Cycle Research and Development

Focused Ion Beam

High Level Waste

Inductively Coupled Plasma - Atomic Emission Spectroscopy

Inductively Coupled Plasma - Mass Spectroscopy

Los Alamos National Laboratory

Lanthanides

Noble Metals

Product Consistency Test

Pacific Northwest National Laboratory

Reduction/Oxidation

Scanning Electron Microscopy

Spark Plasma Sintering

Savannah River National Laboratory

Trivalent Actinide - Lanthanide Separation by Phosphorous reagent

Extraction from Aqueous Komplexes

Transmission Electron Microscopy

Transition Metals

Transuranic Extraction

X-ray Diffraction 


\section{ACKNOWLEDGEMENTS}

The authors would like to thank Professor Serge Stefanovsky of SIA-Radon and Dr. James Marra of SRNL for their insight and suggestions into potential compositions for the host ceramic phases, and David Best, David Missimer, Elise Fox, Phyllis Workman, Pat Simmons, Whitney Riley, Mark Jones, and Curtis Johnson of SRNL for their assistance with sample preparation and characterization.

\section{Government License Notice}

This work was prepared under an agreement with and funded by the U.S. Government. Neither the U. S. Government or its employees, nor any of its contractors, subcontractors or their employees, makes any express or implied: 1 . warranty or assumes any legal liability for the accuracy, completeness, or for the use or results of such use of any information, product, or process disclosed; or 2. representation that such use or results of such use would not infringe privately owned rights; or 3. endorsement or recommendation of any specifically identified commercial product, process, or service. Any views and opinions of authors expressed in this work do not necessarily state or reflect those of the United States Government, or its contractors, or subcontractors.

This document has been created by Savannah River Nuclear Solutions, LLC, Operator of Savannah River National Laboratory under Contract No. DE-AC09-08SR22470. The U.S. Government retains for itself, and others acting on its behalf, a paid-up nonexclusive, irrevocable worldwide license in said article to reproduce, prepare derivative works, distribute copies to the public, and perform publicly and display publicly, by or on behalf of the Government.

This work was supported by the U.S. Department of Energy, Office of Nuclear Energy, under Contract DE-AC02-06CH11357. 


\section{INTRODUCTION}

Efforts being conducted by the United States Department of Energy (DOE) under the Fuel Cycle Research and Development (FCR\&D) program are aimed at demonstrating a proliferation-resistant, integrated nuclear fuel cycle. The envisioned fuel reprocessing technology would separate the fuel into several fractions, thus partitioning the waste into groups with common chemistry. With these partitioned waste streams, it is possible to treat waste streams separately or combine waste streams for treatment when it is deemed appropriate. A trade study conducted in 2008 concluded that it was beneficial from a cost perspective to combine waste streams and treat them using existing waste form technologies. ${ }^{1} \mathrm{~A}$ borosilicate glass was identified as the preferred waste form for the Cs/Sr (CS), lanthanide (LN) and transition metal fission product (TM) combined waste stream. Unfortunately, several fission products (e.g. noble metals and molybdenum) have limited solubility in borosilicate glasses. Therefore, the use of borosilicate glass may simplify waste form processing but result in significant increases in waste form volumes. This would defeat a major advanced fuel cycle reprocessing objective of minimizing high level waste form volumes.

A joint fiscal year 2009 study by the Pacific Northwest National Laboratory (PNNL) and the Savannah River National Laboratory (SRNL) developed baseline borosilicate glass waste forms for three projected waste streams resulting from the Advanced Fuel Cycle Initiative (AFCI) aqueous separations process. ${ }^{2}$ While the study identified acceptable glass compositions for a CS/LN/TM with high $\mathrm{MoO}_{3}$ waste composition and a CS/LN/TM with high noble metals (NM) waste composition, the waste loading was found to be limited by both Mo and NM concentrations. Additionally, several of the glasses fabricated for the CS/LN-only waste composition underwent massive crystallization upon slow cooling. Chemical durability testing indicated the excellent leaching resistance of these crystalline materials, with many of the crystallized glasses having better leaching resistance than the amorphous glass compositions developed for the other waste streams. Based on these observations, the team developed a renewed interest in exploring crystalline-type waste forms either in a completely crystalline phase assemblage or as crystalline phases within a glassy matrix, which became the focus for fiscal year 2010 studies.

SRNL developed a series of ceramic waste forms in fiscal year 2010 for the immobilization of CS/LN and CS/LN/TM waste streams. ${ }^{3}$ Simple raw materials, including $\mathrm{Al}_{2} \mathrm{O}_{3}, \mathrm{CaO}$, and $\mathrm{TiO}_{2}$ were combined with simulated waste components to produce multiphase ceramics containing hollandite-type phases, perovskites (particularly $\mathrm{BaTiO}_{3}$ ), pyrochlores, zirconolite, and other minor metal titanate phases. Identification of excess $\mathrm{Al}_{2} \mathrm{O}_{3}$ via X-ray Diffraction (XRD) and Scanning Electron Microscopy with Energy Dispersive Spectroscopy (SEM/EDS) in the first series of compositions led to a Phase II study, with significantly reduced $\mathrm{Al}_{2} \mathrm{O}_{3}$ concentrations and increased waste loadings. Three fabrication methodologies were used, including melting and crystallizing, pressing and sintering, and Spark Plasma Sintering (SPS), with the intent of studying phase evolution under various sintering conditions. XRD and SEM/EDS results showed that the partitioning of the waste elements in the sintered materials was very similar, despite varying stoichiometry of the phases formed. The Phase II compositions generally contained a reduced amount of unreacted $\mathrm{Al}_{2} \mathrm{O}_{3}$ as identified by XRD, and had phase assemblages that were closer to the targeted phase types. Chemical composition measurements showed no significant issues with meeting the target compositions, although volatilization of Cs and Mo was identified. Partitioning of the major waste components was determined via XRD. SEM/EDS mapping showed that those elements, which were generally present in small concentrations, were well distributed throughout the waste forms. ${ }^{3}$

Preliminary studies of radiation damage tolerance using ion beam irradiation at Los Alamos National Laboratory (LANL) showed little if any modification of the material after irradiation, although a need for additional study in this area was identified. ${ }^{3}$ Chemical durability was studied using the Product Consistency Test (PCT). Most of the elements measured were retained by the ceramic waste forms, 
indicating good chemical durability. Cs, Mo, and $\mathrm{Rb}$ were released at somewhat higher rates as compared to the matrix components, although a need for benchmark compositions and additional characterization was identified in order to qualify the PCT results. ${ }^{3}$

The fiscal year 2011 study, which is the focus of this report, continued the development of the crystalline ceramic waste forms. Ceramic waste forms incorporate the radionuclides in the waste as part of their crystalline structure. As such, ceramic forms are tailored to create certain minerals (i.e. unique crystalline structures) that will host the radionuclides by binding them at specific sites within their crystalline structure. These synthetic minerals are made to reflect natural minerals that host natural radioactive species such as uranium, nonradioactive isotopes of the fission products, or both. Tailoring of a ceramic waste form in this study is based on the knowledge that there are many naturally occurring minerals containing radioactive and non-radioactive species very similar to the radionuclides of concern in wastes from fuel reprocessing, and that these minerals can exhibit excellent chemical durability.

Titanate ceramics have been thoroughly studied for use in immobilizing nuclear wastes (e.g., the SYNROC family) due to their natural resistance to leaching in water. ${ }^{4,5}$ Assemblages of several titanate phases have been successfully demonstrated to incorporate radioactive waste elements, and the multiphase nature of these materials allows them to accommodate variation in the waste composition. ${ }^{6}$ While these materials are typically densified via hot isostatic pressing, recent work has shown that they can also be produced from a melt. For example, demonstrations have been completed using the Cold Crucible Induction Melter (CCIM) technology to produce several crystalline ceramic waste forms, including murataite-rich ceramics, ${ }^{7}$ zirconolite/pyrochlore ceramics, ${ }^{8}$ Synroc-C (zirconolite, hollandite, perovskite), ${ }^{9}$ aluminotitanate ceramics, and zirconia. ${ }^{10}$ This production route is advantageous since melters are already in use for defense high level waste (HLW) vitrification in several countries, and melter technology greatly reduces the potential for airborne contamination as compared to powder handling operations.

Several of the crystalline phases in the multi-phase assemblage are particularly important for incorporation of Cs and Mo species: hollandite and powellite. Hollandite is the proposed ceramic host for Cs, which is difficult to immobilize due to its high volatility at elevated temperature, ability to form water soluble compounds, and potential for long term release during storage. For this reason, Cs is one of the more problematic fission product radionuclides. There are natural analogues of hollandite including ankagite, found in dolomitic marble in the Apuan Alps in Tuscany, Italy. ${ }^{11}$ The hollandite group of minerals has the formula $\mathrm{A}_{\mathrm{x}} \mathrm{B}_{\mathrm{y}} \mathrm{C}_{8-\mathrm{y}} \mathrm{O}_{16}$, with the $\mathrm{B}$ and $\mathrm{C}$ cations surrounded by octahedral configuration of oxygen. ${ }^{12}$ Powellite is a molybdate mineral with a chemical formula of $\mathrm{CaMoO}_{4}$ or $\mathrm{BaMoO}_{4}$, and a tetragonal structure. Powellite is one of the various crystalline secondary alteration phases that form during the corrosion of HLW glasses. Due to its structural variability, powellite can accommodate considerable chemical substitutions including trivalent actinides. ${ }^{13}$

The objectives of the fiscal year 2011 studies at SRNL and LANL were to understand and optimize the process window for crystalline phase formation and to begin fundamental studies of the individual phases identified during the previous year's work with regard to elemental partitioning and chemical durability. In the study described in this report, refinements to waste loading and the concentrations of additives were made to the multiphase waste form based on the results of the previous year's study. Processing parameters, including melt time, cooling rate, and the addition of a calcining step were varied to determine the impacts on crystalline phase assemblage. Two sets of PCT experiments were completed to evaluate the impacts of composition and processing parameters on chemical durability. Three different single phase materials were fabricated to evaluate the chemical durability of the individual phases. The results are discussed in detail here, and recommendations for follow-on work are provided. 


\section{EXPERIMENTAL PROCEDURE}

\subsection{Projected Waste Stream Compositions}

The waste streams that formed the basis of the development testing completed in 2009 continue to be of interest for the 2011 studies, and are given in Table 2-1. The CS/LN composition is the result of a combination of the $\mathrm{Cs} / \mathrm{Sr}$ separated stream and the Trivalent Actinide - Lanthanide Separation by Phosphorous reagent Extraction from Aqueous Komplexes (TALSPEAK) waste stream consisting of lanthanide fission products. ${ }^{14}$ The CS/LN/TM streams are comprised of the Cs/Sr stream, the lanthanide stream, and the transition metal fission product waste stream resulting from the transuranic extraction (TRUEX) process. The TM stream varies significantly due to uncertainty in volatile-oxidation separations efficiency for noble metals, partitioning of noble metals to undissolved solids, Mo and $\mathrm{Zr}$ concentrations in the undissolved solids and amount of Zr-molybdates precipitated during processing. Therefore, two variants of the CS/LN/TM combined waste streams have been used in waste form studies. The CS/LN/TM High Mo waste stream variant ${ }^{14}$ has a high molybdenum concentration with relatively low noble metal concentrations, while the CS/LN/TM High NM variant ${ }^{15}$ has high noble metal concentrations and less Mo. The combined CS/LN/TM High Mo waste stream was selected as the focus of the current work since Mo is expected to present difficulties in phase formation in the ceramic. Furthermore, although the noble metals in the CS/LN/TM High NM waste stream are expected to exhibit low solubility, it is expected that the noble metals will remain relatively inert within the ceramic matrix. 
Table 2-1. Projected Waste Stream Compositions (wt \%) for Waste Form Development. ${ }^{14,15}$

\begin{tabular}{||c|c|c|c||}
\hline \hline Oxide & CS/LN & $\begin{array}{c}\text { CS/LN/TM } \\
\text { High Mo }\end{array}$ & $\begin{array}{c}\text { CS/LN/TM } \\
\text { High NM }\end{array}$ \\
\hline $\mathrm{Ag}_{2} \mathrm{O}$ & - & 0.40 & 0.43 \\
\hline $\mathrm{BaO}$ & 11.55 & 7.83 & 8.47 \\
\hline $\mathrm{Br}$ & - & 0.08 & 0.09 \\
\hline $\mathrm{CdO}$ & - & 0.39 & 0.43 \\
\hline $\mathrm{Ce}_{2} \mathrm{O}_{3}$ & 15.28 & 11.01 & 11.91 \\
\hline $\mathrm{Cs}_{2} \mathrm{O}$ & 15.08 & 10.22 & 11.05 \\
\hline $\mathrm{Eu}_{2} \mathrm{O}_{3}$ & 0.89 & 0.61 & 0.66 \\
\hline $\mathrm{Gd}_{2} \mathrm{O}_{3}$ & 0.84 & 0.57 & 0.62 \\
\hline $\mathrm{In}_{2} \mathrm{O}_{3}$ & - & 0.01 & 0.01 \\
\hline $\mathrm{La}_{2} \mathrm{O}_{3}$ & 8.21 & 5.62 & 6.08 \\
\hline $\mathrm{MoO}_{3}$ & - & 13.88 & 3.00 \\
\hline $\mathrm{Nd}_{2} \mathrm{O}_{3}$ & 27.11 & 18.56 & 20.07 \\
\hline $\mathrm{PdO}$ & - & 0.06 & 5.73 \\
\hline $\mathrm{Pm}_{2} \mathrm{O}_{3}$ & 0.08 & 0.06 & 0.06 \\
\hline $\mathrm{Pr}_{2} \mathrm{O}_{3}$ & 7.51 & 5.14 & 5.56 \\
\hline $\mathrm{Rb}_{2} \mathrm{O}$ & 2.22 & 1.50 & 1.63 \\
\hline $\mathrm{Rh}_{2} \mathrm{O}_{3}$ & - & 0.28 & 1.21 \\
\hline $\mathrm{RuO}_{2}$ & - & 0.70 & 6.20 \\
\hline $\mathrm{Sb}_{2} \mathrm{O}_{3}$ & - & 0.04 & 0.05 \\
\hline $\mathrm{SeO}_{2}$ & - & 0.29 & 0.32 \\
\hline $\mathrm{Sm}_{2} \mathrm{O}_{3}$ & 5.58 & 3.82 & 4.13 \\
\hline $\mathrm{SnO}_{2}$ & - & 0.25 & 0.27 \\
\hline $\mathrm{SrO}_{2}$ & 5.14 & 3.49 & 3.77 \\
\hline $\mathrm{Tb}_{2} \mathrm{O}_{3}$ & 0.02 & 0.01 & 0.01 \\
\hline $\mathrm{TeO}_{2}$ & - & 2.33 & 2.52 \\
\hline $\mathrm{Y}_{2} \mathrm{O}_{3}$ & 0.49 & 2.23 & 2.41 \\
\hline $\mathrm{ZrO}_{2}$ & - & 10.60 & 3.33 \\
\hline & & & \\
\hline
\end{tabular}

\subsection{Design of Ceramic Host Systems}

Ceramic host systems for this study were selected based on the objectives of forming durable titanate and aluminate phases, using a minimum of additives to form the desired phases (i.e., maximizing waste loadings), and fabrication from a melt. Targeted compositions for ceramic waste forms are given in Table 2-2. The additives used were $\mathrm{Al}_{2} \mathrm{O}_{3}, \mathrm{CaO}$, and $\mathrm{TiO}_{2}$. The targeted waste loadings ranged from 30$50 \mathrm{wt} \%$. These waste loadings were chosen to be lower than the previous year's study due to concerns that high waste loadings may lead to issues with decay heat in repository storage. The concentrations of $\mathrm{Al}_{2} \mathrm{O}_{3}$ added were reduced since excess $\mathrm{Al}_{2} \mathrm{O}_{3}$ was identified in several of the previous waste forms. ${ }^{3}$ The alkali and alkaline earth elements in the waste were anticipated to partition to aluminotitanate phases approximating hollandite or $(\mathrm{Ba}, \mathrm{Cs}, \mathrm{Rb})\left(\mathrm{Al}, \mathrm{Ti}_{2}\right)_{2} \mathrm{Ti}_{6} \mathrm{O}_{16}$. The lanthanides were anticipated to partition to aluminate perovskites $\left(\mathrm{LnAlO}_{3}\right)$. Strontium was anticipated to partition to a titanate perovskite $\left(\mathrm{SrTiO}_{3}\right)$, and $\mathrm{CaO}$ was added to form powellite $(\mathrm{Ca}, \mathrm{Sr}, \mathrm{Cd}) \mathrm{MoO}_{4}$, calzirite $\left(\mathrm{CaZrO}_{3}\right)$, and other minor oxide phases. 
Table 2-2. Targeted Compositions (wt \%) for the CS/LN/TM High Mo Ceramic Waste Forms.

\begin{tabular}{||c|c|c|c||}
\hline Composition & CSLNTM-10 & CSLNTM-11 & CSLNTM-12 \\
\hline Waste & 50 & 40 & 30 \\
\hline $\mathrm{Al}_{2} \mathrm{O}_{3}$ & 3 & 3.6 & 4.2 \\
\hline $\mathrm{TiO}_{2}$ & 40 & 48 & 56 \\
\hline $\mathrm{CaO}$ & 7 & 8.4 & 9.8 \\
\hline
\end{tabular}

Two compositions developed during the FY10 study were used as part of the durability testing to provide the opportunity for comparison. The targeted compositions of these waste forms are provided in Table 2-3. Their development is described in detail in the FY10 summary report. ${ }^{3}$

Table 2-3. Targeted Compositions (wt \%) of Selected CS/LN/TM High Mo Ceramic Waste Forms from the FY10 Study.

\begin{tabular}{|c|c|c||}
\hline Composition & CSLNTM-02 & CSLNTM-06 \\
\hline Waste & 60 & 55 \\
\hline $\mathrm{Al}_{2} \mathrm{O}_{3}$ & 14 & 3 \\
\hline $\mathrm{TiO}_{2}$ & 21 & 35 \\
\hline $\mathrm{CaO}$ & 5 & 7 \\
\hline
\end{tabular}

\subsection{Fabrication Methods}

Simulated waste material and the ceramic forming additives were blended in the appropriate ratios via ball milling. Two different fabrication methods were used to densify the ceramic waste forms: melting and crystallizing, and cold pressing followed by pressureless sintering. Both methods were performed in laboratory air. The intent was to provide insight into the phase assemblage that was formed at varying proximity to equilibrium conditions. These fabrication steps are described in further detail below.

\subsubsection{Simulated Waste and Additives}

A large batch of simulated waste material (the CS/LN/TM High Mo composition in Table 2-1) was prepared from the proper amounts of reagent grade metal oxides and carbonates. Five of the very minor components, including $\mathrm{Br}, \mathrm{In}_{2} \mathrm{O}_{3}, \mathrm{Pm}_{2} \mathrm{O}_{3}, \mathrm{Sb}_{2} \mathrm{O}_{3}$, and $\mathrm{Tb}_{2} \mathrm{O}_{3}$, were omitted from the simulated waste since their very low projected concentrations were not anticipated to impact phase formation or chemical durability. The powders were ball milled in a mixture of 50\% ethyl alcohol and 50\% deionized water inside a polyethylene jar with flat-ended cylindrical alumina media for 15 minutes. The blended powders were dried overnight at $70^{\circ} \mathrm{C}$. Smaller batches of each of the waste forms were then prepared by combining a portion of the simulated waste material with the appropriate amounts of reagent grade $\mathrm{Al}_{2} \mathrm{O}_{3}$, $\mathrm{TiO}_{2}$, and $\mathrm{CaO}$. The powders were again ball milled in an ethyl alcohol and water mixture and dried to produce batch material for each of the densification methods.

\subsubsection{Melting and Crystallizing}

Samples of each of the ceramic materials were melted in an electric resistance heated furnace to simulate melter production. The blended and dried powders were placed into $\mathrm{Pt} / \mathrm{Rh}$ alloy crucibles and melted at $1500{ }^{\circ} \mathrm{C}$ for 1 hour. Power to the furnace was then turned off with the crucibles remaining inside to cool slowly (furnace cooling) to roughly approximate the slow cooling conditions experienced by a waste form poured from a melter into a canister. The temperature of the furnace during cooling was recorded, and 
representative data are plotted in Figure 2-1. The temperature of the furnace fell below $200{ }^{\circ} \mathrm{C}$ after 6.5 hours of cooling. The crucibles were removed from the furnace once cooled and photographed to document the degree of melting that was visually observed for each composition. As will be described later, the hold time at the melting temperature and the cooling rate were also varied to determine their impacts on the final crystalline phase assemblage.

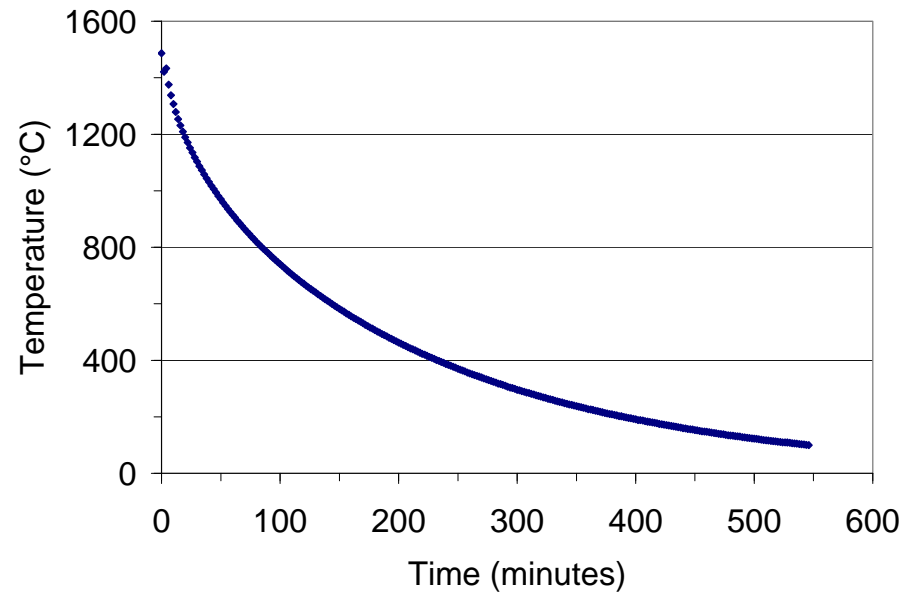

Figure 2-1. Furnace Cooling Profile for the Melt and Crystallize Fabrication Method.

\subsubsection{Calcining}

A sample of composition CSLNTM-11 was calcined followed by melting and crystallizing to determine whether the release of carbonates from the batch material at high temperature affected the volatility of Cs. The intent was to drive the carbonates off at a lower temperature, prior to melting of the batch. Approximately $25 \mathrm{~g}$ of the batch material was placed in a $\mathrm{Pt} / \mathrm{Rh}$ crucible and set in a furnace at $650{ }^{\circ} \mathrm{C}$ for two hours. The furnace was then ramped up to $900{ }^{\circ} \mathrm{C}$ and held for two hours. The crucible was then removed from the furnace, and the furnace temperature was increased to $1500{ }^{\circ} \mathrm{C}$. The crucible was placed back in the furnace when it reached $1500^{\circ} \mathrm{C}$ and held for 30 minutes. Power to the furnace was then turned off and the crucible cooled inside the furnace (furnace cooling).

A sample of the simulated CS/LN/TM High Mo waste material was calcined to be used for comparison in durability testing. Approximately $20 \mathrm{~g}$ of the simulated waste material (see Table 2-1) was placed in a $\mathrm{Pt} / \mathrm{Rh}$ crucible and set in a furnace at $650{ }^{\circ} \mathrm{C}$ for 2 hours. The furnace temperature was then ramped up to $900{ }^{\circ} \mathrm{C}$ and held for two hours. The crucible was removed from the furnace after the second hold and cooled in air to room temperature.

\subsubsection{Single Phase Melts}

Samples of the single phase materials $\mathrm{CaMoO}_{4}, \mathrm{BaMoO}_{4}$, and $\mathrm{BaAl}_{2} \mathrm{Ti}_{6} \mathrm{O}_{16}$ were prepared by melting and crystallizing. Stoichiometric batches for each composition were prepared using reagent grade oxides and carbonates. The batches were melted in $\mathrm{Pt} / \mathrm{Rh}$ crucibles in an electrically heated furnace. The $\mathrm{CaMoO}_{4}$ and $\mathrm{BaMoO}_{4}$ batches were melted at $1500{ }^{\circ} \mathrm{C}$ for 20 minutes. The $\mathrm{BaAl}_{2} \mathrm{Ti}_{6} \mathrm{O}_{16}$ batch was melted at $1550^{\circ} \mathrm{C}$. The melting temperatures were determined via visual observations over a range of temperatures using smaller test melts. The phase development of the samples prepared from melts was compared with the crystalline phases formed from powder batches calcined at 900 to $1100{ }^{\circ} \mathrm{C}$ for four hours. 


\subsubsection{Cold Pressing and Sintering for Extended Periods}

Sintering of pellets for longer periods was used to approximate equilibrium conditions and allow the more stable phases to form within each composition. The blended and dried powders were cold pressed into pellets using a steel die and uniaxial hydraulic press. Thermal analysis, conducted as a screening tool for crystallization and melting point determination, indicated that a majority of the compositions displayed initial melting point endotherms in the range of $1280-1300^{\circ} \mathrm{C}$. The pellets were sintered in an electric resistance heated furnace at $1200^{\circ} \mathrm{C}$ in air for 25 hours and furnace cooled.

\subsection{Characterization of Crystalline Waste Forms}

\subsubsection{X-ray Diffraction}

Representative samples of each ceramic waste form were analyzed by XRD to determine their crystalline phase assemblage. Samples were run under conditions providing a detection limit of approximately 0.5 vol \%. That is, if crystals were present at $0.5 \mathrm{vol} \%$ or greater, the diffractometer would allow a qualitative determination of the type of crystalline phases present. Samples were ground prior to analysis. Quantitative XRD was performed for some of the samples using an $\mathrm{Al}_{2} \mathrm{O}_{3}$ internal standard.

\subsubsection{Chemical Compositions}

Representative samples of select compositions were characterized to confirm that the as-fabricated ceramics met the targeted compositions. The samples were prepared using lithium-metaborate and sodium peroxide fusions followed by acid dissolution. The resulting solutions were analyzed by Inductively Coupled Plasma - Atomic Emission Spectroscopy (ICP-AES) and Inductively Coupled Plasma - Mass Spectroscopy (ICP-MS). Two measurements were taken for each element of interest, and the average of these two measurements was reported as the measured value.

\subsubsection{Electron Microscopy and Elemental Analysis}

SEM and EDS analyses were performed at LANL on select samples. Specimens were cut, ground, and polished with alumina lapping films to produce a flat surface for imaging and analysis. All of the samples were final polished using $40 \mathrm{~nm}$ colloidal silica slurry ${ }^{a}$ to remove mechanical polishing damage. Secondary electron and backscattered electron imaging were used to identify grain size and morphology, as well as general homogeneity of the specimen. EDS elemental mapping was used to identify partitioning of the waste elements among the various phases.

\subsubsection{Chemical Durability}

The ASTM C1285 Product Consistency Test (PCT) Method B was used to provide a preliminary measure of the chemical durability of the ceramic waste forms. This test was used to provide insight into the rate of leaching of the waste elements from the ceramic materials due to the relative ease of performing the experiments and the relatively short time period (7 days) needed for testing, although it may not be the optimal method for estimating the repository performance of these waste forms.

Samples of each waste form were ground to -100 mesh using a tungsten carbide grinder. All of the fine particulates were used in the PCT due to the small quantities of material available. The surface areas of each individual sample were determined using Brunauer-Emmett-Teller (BET) analysis with nitrogen or

\footnotetext{
${ }^{a}$ Syton HT50, DuPont AirProducts NanoMaterials L.L.C, Tempe, AZ.
} 
krypton as the analysis gas prior to performing the PCT. No washing steps were performed since the removal of fine particles would invalidate the BET results. The PCT Method-B was performed on the selected samples in two sets. Also included were samples of the Approved Reference Material (ARM) glass, the Environmental Assessment (EA) glass, and blanks from the vessel cleaning batches. Stainless steel vessels were used with $15 \mathrm{ml}$ of Type-I ASTM water and $1.5 \mathrm{~g}$ of the ground sample. The vessels were sealed placed in an oven at $90{ }^{\circ} \mathrm{C}$ for 7 days. Once cooled, the resulting solutions were filtered and acidified, then analyzed by ICP-AES. Normalized release rates were calculated based on the measured compositions using the averages of the common logarithms of the leachate concentrations. The number of replicates for each composition was dependent upon the amount of material and will be discussed in the results. At least two replicates were used for each composition.

\subsubsection{Ion Beam Irradiation}

Preliminary evaluations of the radiation damage tolerance of select ceramic waste forms were undertaken by subjecting samples to alpha particle irradiation at LANL. In this study, LANL researchers also used proton, and electron irradiations to simulate the self-radiation damage that occurs in a material incorporating nuclides undergoing radioactive decay. Most of the selfirradiation in a waste form incorporating fission products is due to beta particle and gamma emission. These emissions cause radiation damage primarily via radiolytic processes, because both beta and gamma particles induce substantial electronic excitations in a target material. Proton, alpha, and electrons provide a useful means to examine radiolysis effects because they deposit nearly all of their energy in solids via electronic loss processes. 


\section{RESULTS AND DISCUSSION}

\subsection{Fabrication of Ceramic Waste Forms}

Photographs of the CS/LN/TM High Mo waste forms after melting at $1500{ }^{\circ} \mathrm{C}$ for 1 hour and furnace cooling are shown in Figure 3-1. All three of the compositions appear to have melted completely based on visual observations as the crucible were removed from the furnace. The melted and crystallized material did not completely cover the bottom of the crucibles for the CSLNTM-10 and CSLNTM-11 compositions, as seen in Figure 3-1. The formation of multiple morphologies and colors of crystals is visible on the surface of each composition. Visual observations after removal from the crucible indicated that the materials were densified, although some porosity remained visible.

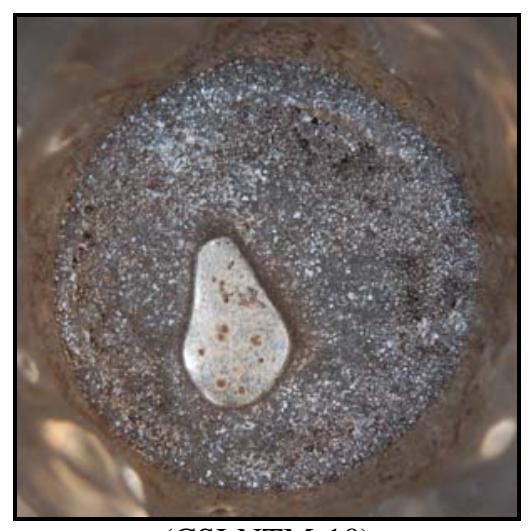

(CSLNTM-10)

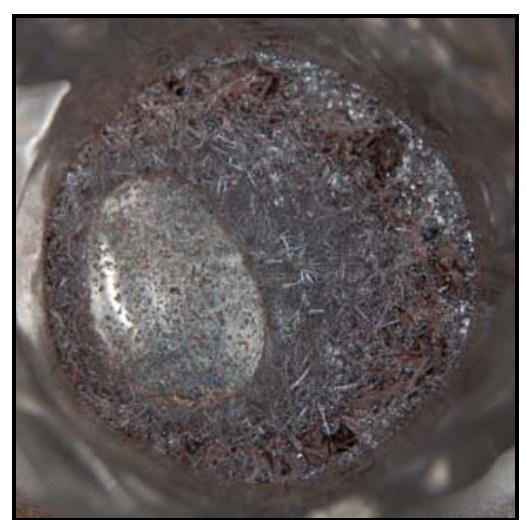

(CSLNTM-11)

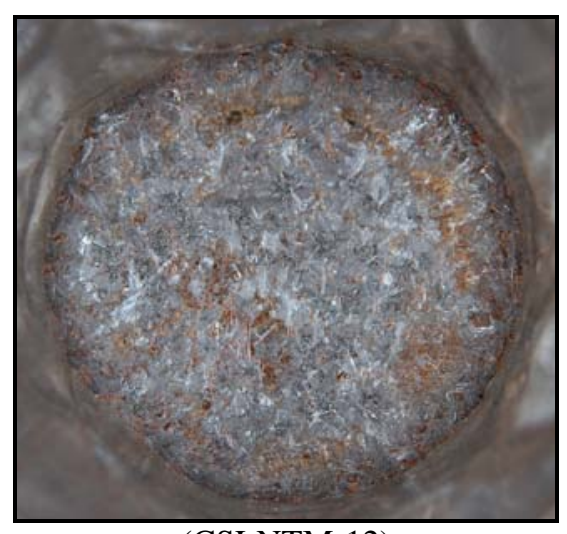

(CSLNTM-12)

Figure 3-1. Photographs of the CS/LN/TM High Mo Waste Forms after Melting and Crystallizing in Pt/Rh Crucibles.

As will be discussed below, composition CSLNTM-11 was selected for additional melt and crystallize experiments. Two additional cooling rate experiments were performed. The uncontrolled furnace cooling gives a cooling rate of approximately $10{ }^{\circ} \mathrm{C} / \mathrm{min}$. through the highest temperature region (see Figure 2-1). Additional batches of composition CSLNTM- 11 were melted at $1500{ }^{\circ} \mathrm{C}$ for 1 hour and then cooled at controlled rates of $5^{\circ} \mathrm{C} / \mathrm{min}$. and $1^{\circ} \mathrm{C} / \mathrm{min}$ to room temperature. There was no noticeable difference in the appearance of these samples after slower cooling as compared to the image in Figure 3-1.

One additional experiment was performed with an extended melt time at temperature. A batch of composition CSLNTM- 11 was melted at $1500^{\circ} \mathrm{C}$ for 6 hours and then furnace cooled. This sample had a different appearance as compared to the sample melted for one hour, as shown in Figure 3-2. Several of the melted and crystallized samples were submitted for chemical composition and XRD analyses. 


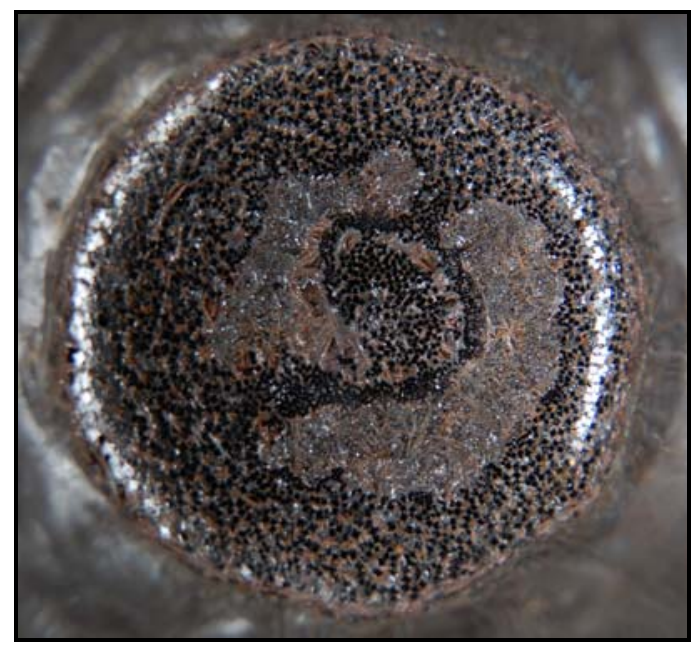

Figure 3-2. Photograph of Composition CSLNTM-11 after Melting at $1500{ }^{\circ} \mathrm{C}$ for 6 Hours and Crystallizing.

The pressed and sintered pellets prepared by extended annealing at $1200{ }^{\circ} \mathrm{C}$ were not fully densified and could be easily broken and crushed to a powder for XRD analyses.

\subsection{Chemical Compositions}

The results of the chemical composition measurements of the ceramic waste forms fabricated by melting and crystallizing are given in Table 3-1. The targeted compositions are included for comparison. In general, most of the components are present at concentrations close to their targeted values. Some (about 20-50\%) of the $\mathrm{Ag}_{2} \mathrm{O}, \mathrm{CdO}$, and $\mathrm{Rb}_{2} \mathrm{O}$ appears to have volatilized during the melting process. Significant amounts (more than 50\%) of the $\mathrm{Cs}_{2} \mathrm{O}, \mathrm{MoO}_{3}, \mathrm{Rh}_{2} \mathrm{O}_{3}, \mathrm{RuO}_{2}, \mathrm{SrO}$, and $\mathrm{TeO}_{2}$ appear to have volatilized as well. This is likely due to the high surface to volume ratio of the test melts (i.e., a small amount of batch material melted in a wide crucible), and may not be reflective of volatilization expected in a full scale melter. Suggestions for reducing volatility will be provided at the end of this report. The volatilization results in the concentrations of some of the other major components, such as $\mathrm{Al}_{2} \mathrm{O}_{3}$ and $\mathrm{TiO}_{2}$, being higher than their targeted values. The measured values for $\mathrm{PdO}$ and $\mathrm{SeO}_{2}$ were below the instrument detection limit, although the targeted concentrations for these components were quite low. Note that the measured sums of oxides are less than $100 \mathrm{wt} \%$, indicating that the dissolution may have been incomplete for some of the elements measured.

The results of the chemical composition measurements of composition CSLNTM-11 as a function of heat treatment are given in Table 3-2. The target compositions are included for comparison. A comparison of the targeted and measured values shows trends that are very similar to those discussed for Table 3-1. Most of the components are present at concentrations close to their targeted values. The concentrations of the more volatile components are shown to be a function of time at temperature. For example, the measured Cs2O concentration was $0.660 \mathrm{wt} \%$ after cooling at $5{ }^{\circ} \mathrm{C} / \mathrm{min}, 0.247 \mathrm{wt} \%$ after cooling at $1 \mathrm{C} / \mathrm{min}$, and 0.011 after heating for six hours at $1500^{\circ} \mathrm{C}$. The greatest impact of volatility occurred for the material melted for six hours at $1500^{\circ} \mathrm{C}$. Again, this may not be reflective of volatilization expected in a full scale melter and suggestions for future work will be provided later. 
Table 3-1. Targeted and Measured Compositions (wt \%) of the Ceramic Waste Forms Fabricated by Melting and Crystallizing.

\begin{tabular}{|c|c|c|c|c|c|c|}
\hline \multirow{2}{*}{ Oxide } & \multicolumn{2}{|c|}{ " CSLNTM-02 } & \multicolumn{2}{|c|}{ " CSLNTM-06 } & \multicolumn{2}{|c|}{ "CSLNTM-11 } \\
\hline & Targeted & Measured & Targeted & Measured & Targeted & Measured \\
\hline $\mathrm{Ag}_{2} \mathrm{O}$ & 0.241 & 0.133 & 0.220 & 0.136 & 0.160 & 0.096 \\
\hline $\mathrm{Al}_{2} \mathrm{O}_{3}$ & 14.000 & 15.226 & 3.000 & 4.360 & 3.600 & 4.198 \\
\hline $\mathrm{BaO}$ & 4.708 & 4.454 & 4.316 & 4.208 & 3.139 & 3.077 \\
\hline $\mathrm{CaO}$ & 5.000 & 5.341 & 7.000 & 7.371 & 8.400 & 8.883 \\
\hline $\mathrm{CdO}$ & 0.235 & 0.089 & 0.215 & 0.105 & 0.156 & 0.075 \\
\hline $\mathrm{Ce}_{2} \mathrm{O}_{3}$ & 6.621 & 7.009 & 6.069 & 6.127 & 4.414 & 4.542 \\
\hline $\mathrm{Cs}_{2} \mathrm{O}$ & 6.146 & 2.693 & 5.633 & 2.525 & 4.097 & 1.635 \\
\hline $\mathrm{Eu}_{2} \mathrm{O}_{3}$ & 0.367 & 0.342 & 0.336 & 0.296 & 0.245 & 0.215 \\
\hline $\mathrm{Gd}_{2} \mathrm{O}_{3}$ & 0.343 & 0.379 & 0.314 & 0.340 & 0.229 & 0.234 \\
\hline $\mathrm{La}_{2} \mathrm{O}_{3}$ & 3.379 & 3.372 & 3.098 & 2.904 & 2.253 & 2.149 \\
\hline $\mathrm{MoO}_{3}$ & 8.346 & 5.348 & 7.651 & 4.566 & 5.564 & 2.934 \\
\hline $\mathrm{Nd}_{2} \mathrm{O}_{3}$ & 11.161 & 11.066 & 10.231 & 9.804 & 7.440 & 7.490 \\
\hline $\mathrm{PdO}$ & 0.036 & $<0.100$ & 0.033 & $<0.100$ & 0.024 & $<0.100$ \\
\hline $\mathrm{Pr}_{2} \mathrm{O}_{3}$ & 3.091 & 3.373 & 2.833 & 2.972 & 2.061 & 2.201 \\
\hline $\mathrm{Rb}_{2} \mathrm{O}$ & 0.902 & 0.616 & 0.827 & 0.571 & 0.601 & 0.446 \\
\hline $\mathrm{Rh}_{2} \mathrm{O}_{3}$ & 0.168 & 0.054 & 0.154 & 0.044 & 0.112 & 0.028 \\
\hline $\mathrm{RuO}_{2}$ & 0.421 & 0.026 & 0.386 & 0.024 & 0.281 & 0.021 \\
\hline $\mathrm{SeO}_{2}$ & 0.174 & $<0.100$ & 0.160 & $<0.100$ & 0.116 & $<0.100$ \\
\hline $\mathrm{Sm}_{2} \mathrm{O}_{3}$ & 2.297 & 2.362 & 2.106 & 2.121 & 1.531 & 1.570 \\
\hline $\mathrm{SnO}_{2}$ & 0.150 & 0.113 & 0.138 & 0.087 & 0.100 & 0.059 \\
\hline $\mathrm{SrO}$ & 2.099 & 1.141 & 1.924 & 1.040 & 1.399 & 0.749 \\
\hline $\mathrm{TeO}_{2}$ & 1.401 & 0.361 & 1.284 & 0.450 & 0.934 & 0.239 \\
\hline $\mathrm{TiO}_{2}$ & 21.000 & 21.333 & 35.000 & 35.802 & 48.000 & 48.559 \\
\hline $\mathrm{Y}_{2} \mathrm{O}_{3}$ & 1.341 & 1.476 & 1.229 & 1.245 & 0.894 & 0.906 \\
\hline $\mathrm{ZrO}_{2}$ & 6.374 & 6.990 & 5.843 & 5.744 & 4.249 & 4.113 \\
\hline Sum & 100.000 & 93.297 & 100.000 & 92.845 & 100.000 & 94.417 \\
\hline
\end{tabular}


Table 3-2. Targeted and Measured Compositions (wt \%) of the Composition CSLNTM-11 Ceramic Waste Form as a Function of Heat Treatment.

\begin{tabular}{||c|c|c|c|c||}
\hline Oxide & Targeted & $\mathbf{5}^{\circ} \mathbf{C} / \mathbf{m i n}$ cooling & $\mathbf{1}^{\circ} \mathbf{C} / \mathbf{m i n}$ cooling & $\mathbf{6}$ hours at $\mathbf{1 5 0 0}{ }^{\circ} \mathbf{C}$ \\
\hline $\mathrm{Ag}_{2} \mathrm{O}$ & 0.160 & 0.153 & 0.118 & 0.042 \\
\hline $\mathrm{Al}_{2} \mathrm{O}_{3}$ & 3.600 & 4.648 & 4.365 & 4.563 \\
\hline $\mathrm{BaO}$ & 3.139 & 3.411 & 3.377 & 3.701 \\
\hline $\mathrm{CaO}$ & 8.400 & 9.284 & 9.564 & 9.291 \\
\hline $\mathrm{CdO}$ & 0.156 & 0.050 & 0.020 & $<0.010$ \\
\hline $\mathrm{Ce}_{2} \mathrm{O}_{3}$ & 4.414 & 4.732 & 4.832 & 4.761 \\
\hline $\mathrm{Cs}_{2} \mathrm{O}$ & 4.097 & 0.660 & 0.247 & 0.011 \\
\hline $\mathrm{Eu}_{2} \mathrm{O}_{3}$ & 0.245 & 0.223 & 0.218 & 0.211 \\
\hline $\mathrm{Gd}_{2} \mathrm{O}_{3}$ & 0.229 & 0.242 & 0.237 & 0.233 \\
\hline $\mathrm{La}_{2} \mathrm{O}_{3}$ & 2.253 & 2.252 & 2.275 & 2.240 \\
\hline $\mathrm{MoO}_{3}$ & 5.564 & 1.673 & 1.231 & 1.157 \\
\hline $\mathrm{Nd}_{2} \mathrm{O}_{3}$ & 7.440 & 7.826 & 8.007 & 7.739 \\
\hline $\mathrm{PdO}$ & 0.024 & $<0.100$ & $<0.100$ & $<0.100$ \\
\hline $\mathrm{Pr}_{2} \mathrm{O}_{3}$ & 2.061 & 2.370 & 2.376 & 2.317 \\
\hline $\mathrm{Rb}_{2} \mathrm{O}$ & 0.601 & 0.232 & 0.109 & 0.049 \\
\hline $\mathrm{Rh}_{2} \mathrm{O}_{3}$ & 0.112 & 0.011 & 0.012 & 0.005 \\
\hline $\mathrm{RuO}_{2}$ & 0.281 & 0.012 & 0.012 & 0.004 \\
\hline $\mathrm{SeO}_{2}$ & 0.116 & $<0.100$ & $<0.100$ & $<0.100$ \\
\hline $\mathrm{Sm}_{2} \mathrm{O}_{3}$ & 1.531 & 1.531 & 1.577 & 1.531 \\
\hline $\mathrm{SnO}_{2}$ & 0.100 & 0.058 & 0.057 & 0.054 \\
\hline $\mathrm{SrO}_{\mathrm{TeO}}$ & 1.399 & 0.668 & 0.648 & 0.644 \\
\hline $\mathrm{TiO}_{2}$ & 0.934 & $<0.100$ & $<0.100$ & $<0.100$ \\
\hline $\mathrm{Y}_{2} \mathrm{O}_{3}$ & 0.894 & 0.806 & 50.639 & 50.889 \\
\hline $\mathrm{ZrO}_{2}$ & 4.249 & 4.133 & 4.086 & 0.790 \\
\hline $\mathrm{Sum}$ & 100.000 & 94.530 & 94.781 & 4.630 \\
\hline \hline
\end{tabular}


The results of the chemical composition measurements of three additional samples are given in Table 3-3, including composition CSLNTM-11 fabricated by pressing and sintering, CSLNTM-11 fabricated by calcining the batch material followed by melting and crystallizing, and the simulated CS/LN/TM High Mo waste material after calcining with no additives. The target compositions are included for comparison. The measured values for the CSLNTM-11 material fabricated by pressing and sintering show a high degree of volatile loss for $\mathrm{Cs}_{2} \mathrm{O}, \mathrm{MoO}_{3}, \mathrm{Rb}_{2} \mathrm{O}, \mathrm{RuO}_{2}$, and $\mathrm{TeO}_{2}$. The amount of volatile loss was larger than that for the melted and crystallized materials. This is not surprising given that this sample was sintered for a period of 25 hours at $1200{ }^{\circ} \mathrm{C}$. The other components are close to their targeted values. A comparison of the measured values for the CSLNTM-11 sample that was calcined prior to melting and crystallizing with its counterpart that was not calcined (see the right side of Table 3-1) shows that there was no reduction in volatilization when the calcination step was added to the fabrication process. The measured values for the simulated CS/LN/TM High Mo waste material after calcining show that volatilization was not an issue for the calcining process alone. The measured concentrations of $\mathrm{Cs}_{2} \mathrm{O}$, $\mathrm{MoO}_{3}, \mathrm{Rb}_{2} \mathrm{O}, \mathrm{RuO}_{2}$, and $\mathrm{TeO}_{2}$ are close to their targeted values.

Chemical composition results for the single phase materials are given along with their targeted values in Table 3-4. The measured concentrations are close to their targeted values for the $\mathrm{CaMoO}_{4}$ and $\mathrm{BaMoO}_{4}$. There is some discrepancy between the targeted and measured values for the $\mathrm{BaAl}_{2} \mathrm{Ti}_{6} \mathrm{O}_{16}$ material. The low sum of oxides for this sample indicates that there may have been some difficulty in fully dissolving the material for analysis. However, the production of the targeted phases was verified by XRD, as will be discussed below. These composition measurements were used in normalizing the PCT data for all samples. 
Table 3-3. Targeted and Measured Compositions (wt \%) of Additional Ceramic Waste Forms and the Simulated, Calcined Waste Material.

\begin{tabular}{|c|c|c|c|c|c|c|}
\hline \multirow[t]{2}{*}{ Oxide } & \multicolumn{2}{|c|}{$\begin{array}{c}\text { CSLNTM-11, } \\
\text { Pressed and Sintered }\end{array}$} & \multicolumn{2}{|c|}{$\begin{array}{c}\text { CSLNTM-11, } \\
\text { Calcined Prior to Melting }\end{array}$} & \multicolumn{2}{|c|}{$\begin{array}{c}\text { CS/LN/TM High Mo } \\
\text { Simulated, Calcined Waste Only }\end{array}$} \\
\hline & Targeted & Measured & Targeted & Measured & Targeted & Measured \\
\hline $\mathrm{Ag}_{2} \mathrm{O}$ & 0.160 & 0.087 & 0.160 & 0.176 & 0.401 & 0.421 \\
\hline $\mathrm{Al}_{2} \mathrm{O}_{3}$ & 3.600 & 4.450 & 3.600 & 4.865 & 0.000 & - \\
\hline $\mathrm{BaO}$ & 3.139 & 3.562 & 3.139 & 3.188 & 7.847 & 7.486 \\
\hline $\mathrm{CaO}$ & 8.400 & 8.941 & 8.400 & 8.185 & 0.000 & - \\
\hline $\mathrm{CdO}$ & 0.156 & 0.017 & 0.156 & 0.082 & 0.391 & 0.303 \\
\hline $\mathrm{Ce}_{2} \mathrm{O}_{3}$ & 4.414 & 4.375 & 4.414 & 4.088 & 11.034 & 10.061 \\
\hline $\mathrm{Cs}_{2} \mathrm{O}$ & 4.097 & 0.042 & 4.097 & 1.767 & 10.243 & 10.219 \\
\hline $\mathrm{Eu}_{2} \mathrm{O}_{3}$ & 0.245 & 0.244 & 0.245 & 0.223 & 0.611 & 0.461 \\
\hline $\mathrm{Gd}_{2} \mathrm{O}_{3}$ & 0.229 & 0.315 & 0.229 & 0.293 & 0.571 & 0.513 \\
\hline $\mathrm{La}_{2} \mathrm{O}_{3}$ & 2.253 & 2.099 & 2.253 & 1.929 & 5.632 & 4.926 \\
\hline $\mathrm{MoO}_{3}$ & 5.564 & 0.837 & 5.564 & 2.881 & 13.911 & 13.698 \\
\hline $\mathrm{Nd}_{2} \mathrm{O}_{3}$ & 7.440 & 7.296 & 7.440 & 6.648 & 18.601 & 16.388 \\
\hline $\mathrm{PdO}$ & 0.024 & $<0.100$ & 0.024 & $<0.100$ & 0.060 & $<0.100$ \\
\hline $\mathrm{Pr}_{2} \mathrm{O}_{3}$ & 2.061 & 2.423 & 2.061 & 2.247 & 5.151 & 4.751 \\
\hline $\mathrm{Rb}_{2} \mathrm{O}$ & 0.601 & 0.026 & 0.601 & 0.381 & 1.503 & 1.607 \\
\hline $\mathrm{Rh}_{2} \mathrm{O}_{3}$ & 0.112 & 0.130 & 0.112 & 0.038 & 0.281 & 0.180 \\
\hline $\mathrm{RuO}_{2}$ & 0.281 & 0.063 & 0.281 & 0.065 & 0.702 & 0.588 \\
\hline $\mathrm{SeO}_{2}$ & 0.116 & $<0.100$ & 0.116 & $<0.100$ & 0.291 & $<0.100$ \\
\hline $\mathrm{Sm}_{2} \mathrm{O}_{3}$ & 1.531 & 1.635 & 1.531 & 1.507 & 3.828 & 3.519 \\
\hline $\mathrm{SnO}_{2}$ & 0.100 & - & 0.100 & - & 0.251 & 0.168 \\
\hline $\mathrm{SrO}$ & 1.399 & 1.608 & 1.399 & 1.466 & 3.498 & 3.524 \\
\hline $\mathrm{TeO}_{2}$ & 0.934 & $<0.100$ & 0.934 & $<0.100$ & 2.335 & 2.064 \\
\hline $\mathrm{TiO}_{2}$ & 48.000 & 48.470 & 48.000 & 46.801 & 0.000 & - \\
\hline $\mathrm{Y}_{2} \mathrm{O}_{3}$ & 0.894 & 0.826 & 0.894 & 0.787 & 2.235 & 2.038 \\
\hline $\mathrm{ZrO}_{2}$ & 4.249 & 4.201 & 4.249 & 4.133 & 10.623 & 9.793 \\
\hline Sum & 100.000 & 91.646 & 100.000 & 91.751 & 100.000 & 92.709 \\
\hline
\end{tabular}


Table 3-4. Targeted and Measured Compositions (wt \%) of the Single Phase Samples Fabricated by Melting and Crystallizing.

\begin{tabular}{|c|c|c|c|c|c|c||}
\hline \multirow{2}{*}{ Oxide } & \multicolumn{2}{|c|}{$\mathrm{CaMoO}_{\mathbf{4}}$} & \multicolumn{2}{c|}{ BaMoO $_{\mathbf{4}}$} & \multicolumn{2}{c||}{$\mathbf{B a A l}_{\mathbf{2}} \mathbf{T i}_{\mathbf{6}} \mathbf{O}_{\mathbf{1 6}}$} \\
\cline { 2 - 7 } & Targeted & Measured & Targeted & Measured & Targeted & Measured \\
\hline $\mathrm{Al}_{2} \mathrm{O}_{3}$ & - & - & - & - & 13.88 & 23.72 \\
\hline $\mathrm{BaO}$ & - & - & 51.58 & 48.27 & 20.88 & 16.18 \\
\hline $\mathrm{CaO}$ & 28.04 & 26.46 & - & - & - & - \\
\hline $\mathrm{MoO}_{3}$ & 71.96 & 68.03 & 48.42 & 46.13 & - & - \\
\hline $\mathrm{TiO}_{2}$ & - & - & - & - & 65.24 & 50.27 \\
\hline $\mathrm{Sum}$ & 100.00 & 94.49 & 100.00 & 94.40 & 100.00 & 90.17 \\
\hline
\end{tabular}




\subsection{Electron Microscopy and Elemental Analysis}

Samples of compositions CSLNTM-06 and CSLNTM-10 fabricated by melting and crystallizing were sent to LANL for SEM/EDS analyses. A backscattered electron micrograph of composition CSLNTM-06 is shown in Figure 3-3. The differences in contrast indicate at least four crystalline phases, with varying grain sizes and morphology. Porosity is visible as the black area near the center of the micrograph. The more angular black areas may indicate grain pullout during polishing. The elements identified in several of the grains via EDS are labeled in the image.

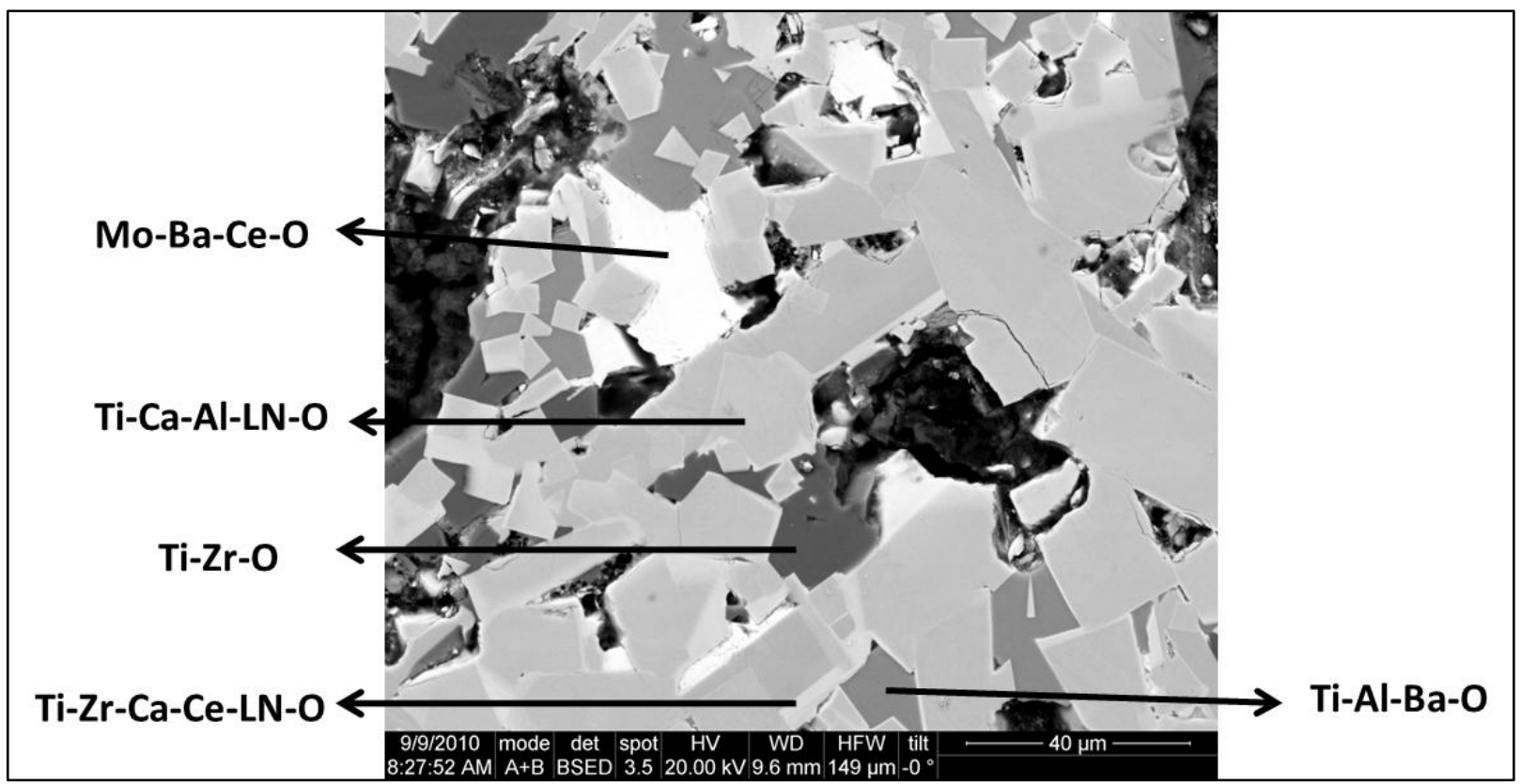

Figure 3-3. Backscattered Electron Micrograph of a Polished Surface of Composition CSLNTM-06 Fabricated by Melting and Crystallizing.

The results of EDS elemental mapping for this sample are shown in Figure 3-4. Observations of these maps show that:

- There is very little, if any, unreacted $\mathrm{Al}_{2} \mathrm{O}_{3}$ present.

- Ba appears to partition mainly to a Ti phase, but is present in all of the phases except for the unreacted $\mathrm{Al}_{2} \mathrm{O}_{3}$.

- Ca appears to partition strongly with Nd and Zr.

- Ce appears to partition most strongly with Mo.

- The Cs signal is too low to clearly distinguish its partitioning.

- $\quad$ Nd and Pr (or the LN elements) appear to partition to the same phases.

- The Sr signal appears to be obscured by the porosity present in the sample. 


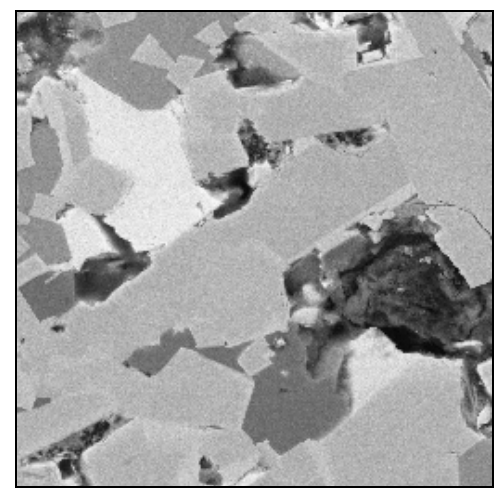

(Secondary Electron Image)

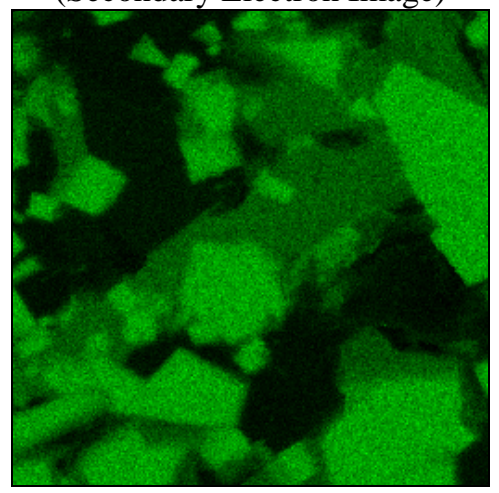

(Ca)

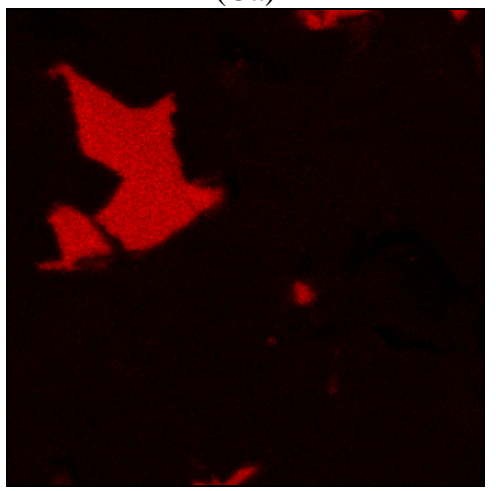

(Mo)

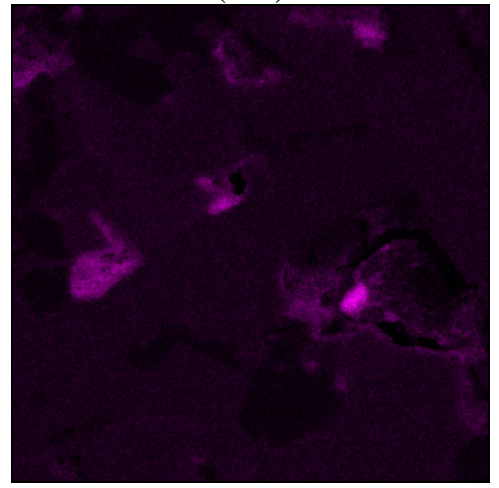

(Sr)

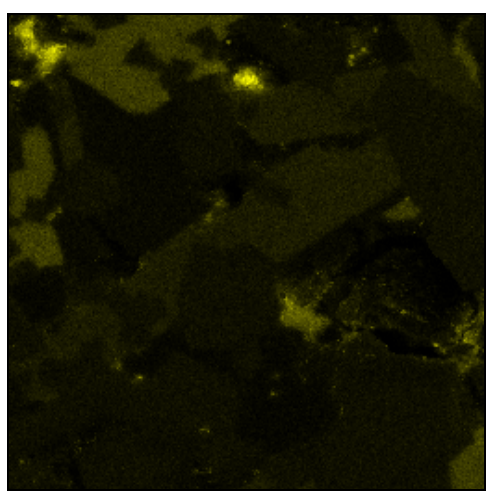

$(\mathrm{Al})$

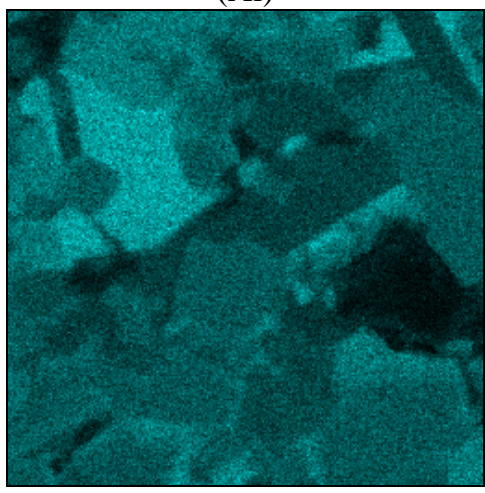

(Ce)

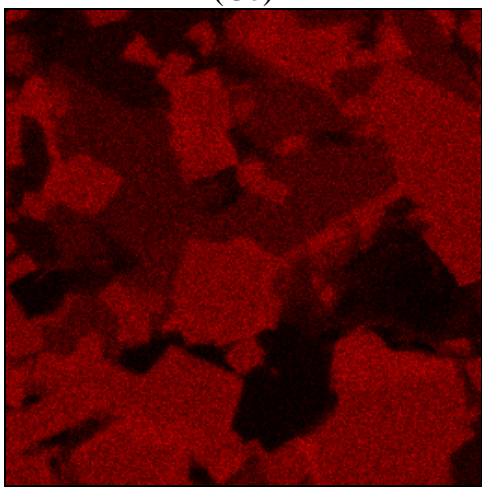

$(\mathrm{Nd})$

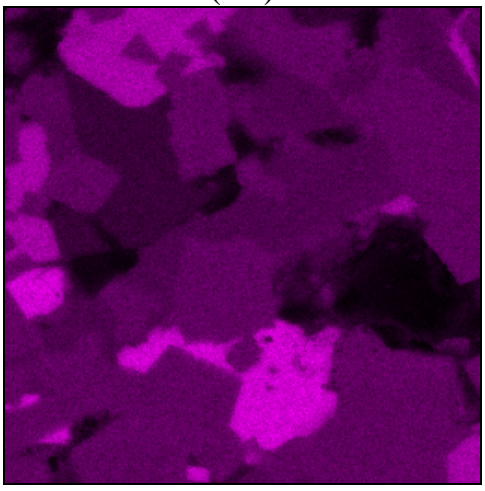

(Ti)

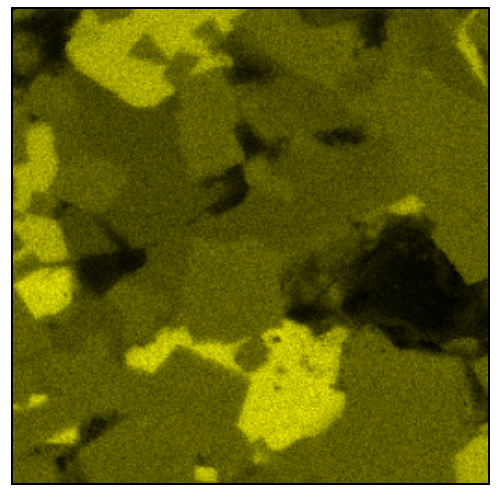

(Ba)

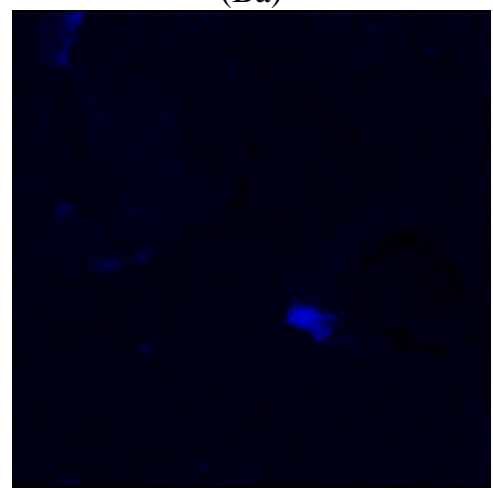

(Cs)

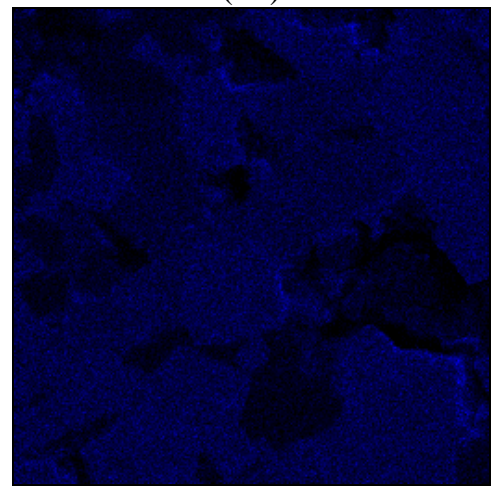

$(\operatorname{Pr})$

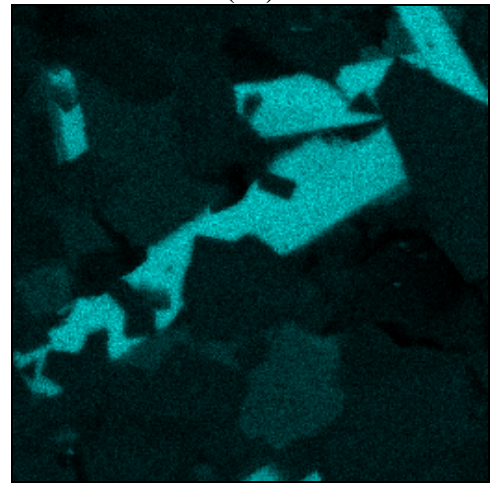

(Zr)

Figure 3-4. EDS Mapping for Select Elements in Composition CSLNTM-06 Fabricated by Melting and Crystallizing. 
A backscattered electron micrograph of composition CSLNTM-10 is shown in Figure 3-5. The backscattered image shows at least four crystalline phases present based on differences in contrast. The phases vary in grain size and morphology. The microstructure appears to be generally similar to that of composition CSLNTM-06 (Figure 3-3).

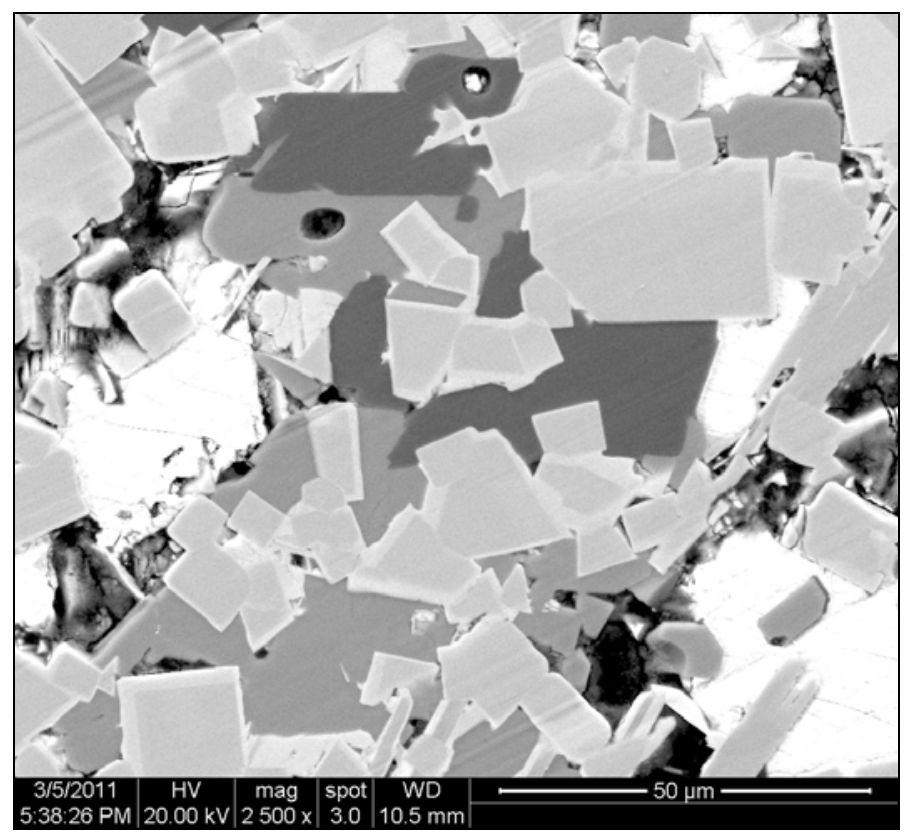

Figure 3-5. Backscattered Electron Micrograph of a Polished Surface of Composition CSLNTM-10 Fabricated by Melting and Crystallizing.

The results of EDS elemental mapping for the CSLNTM-10 sample are shown in Figure 3-6. There are some differences between partitioning in this sample and partitioning in the CSLNTM-06 composition (Figure 3-4). Observations of the maps for composition CSLNTM-10 show that:

- The Al signal appears to be obscured by the porosity in the sample.

- $\mathrm{Ba}$ is distributed throughout the material and is most strongly associated with Ti.

- Ca partitions with Gd, Nd, and Sr.

- Ce and Mo appear to partition to the same phase.

- Oxygen is dispersed throughout the material, as expected.

- The Zr signal is strong in a few grains, but does not appear to be strongly associated with any of the other elements examined. 


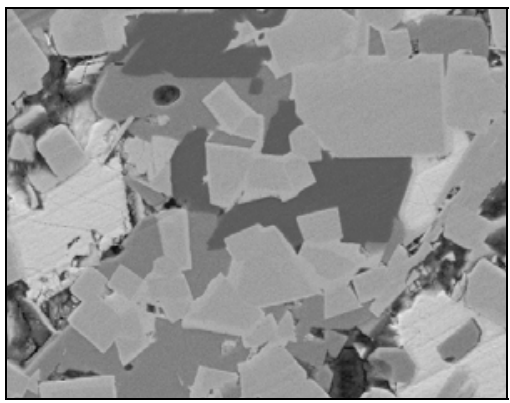

(Secondary electron image)

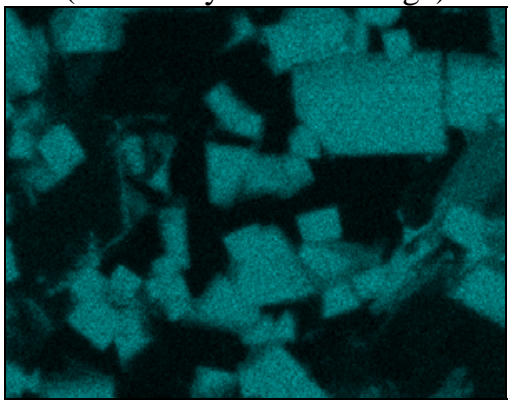

(Ca)

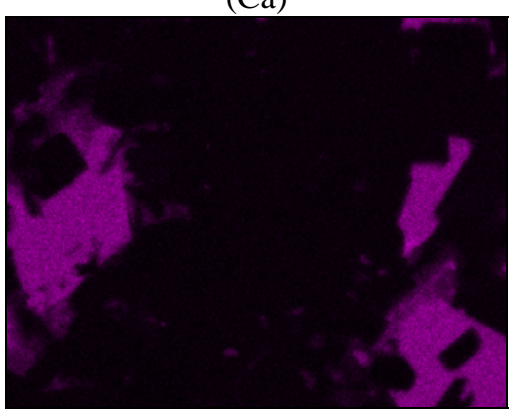

(Mo)

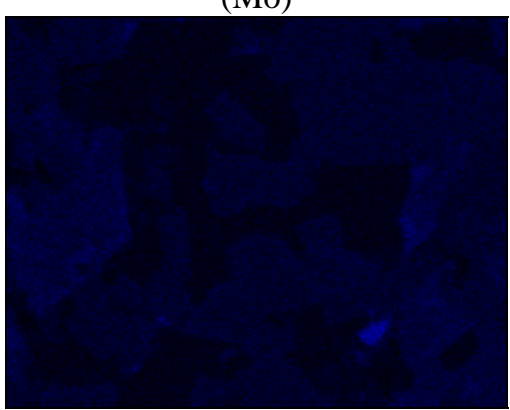

$(\mathrm{Sr})$

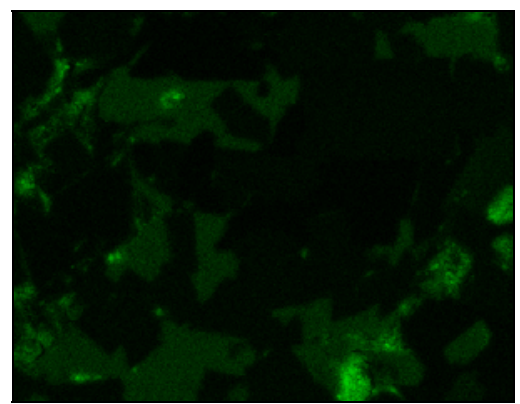

(Al)

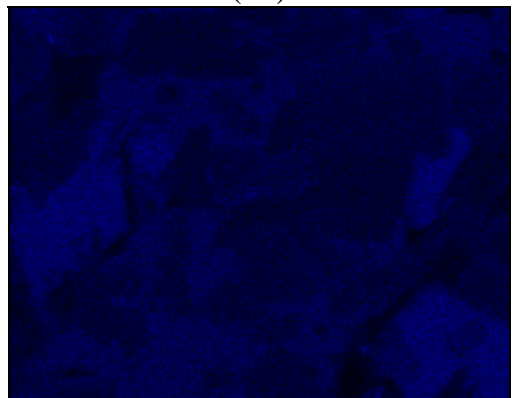

(Ce)

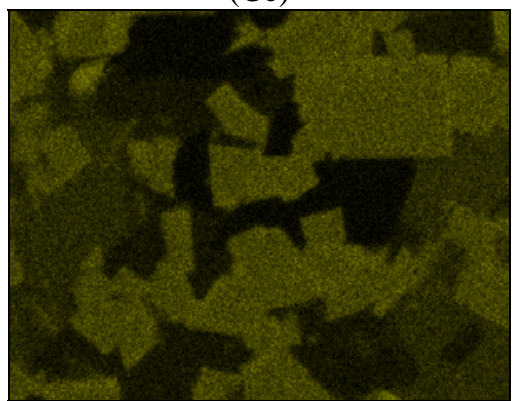

$(\mathrm{Nd})$

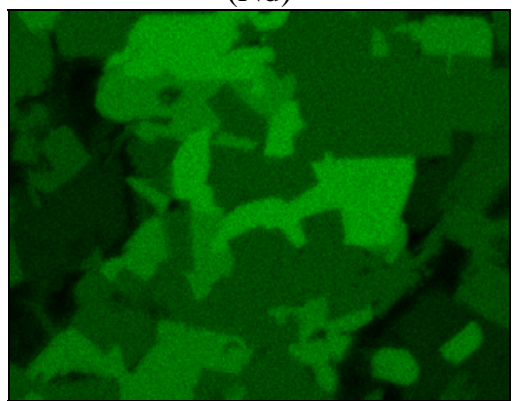

(Ti)

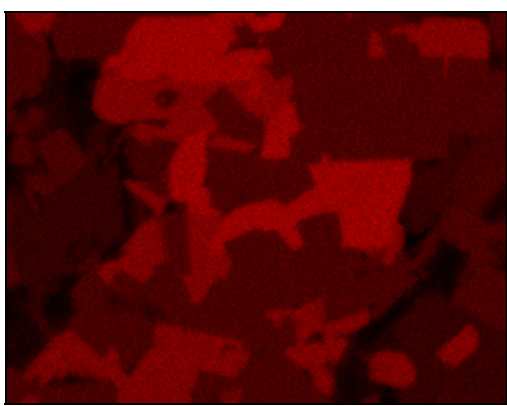

$(\mathrm{Ba})$

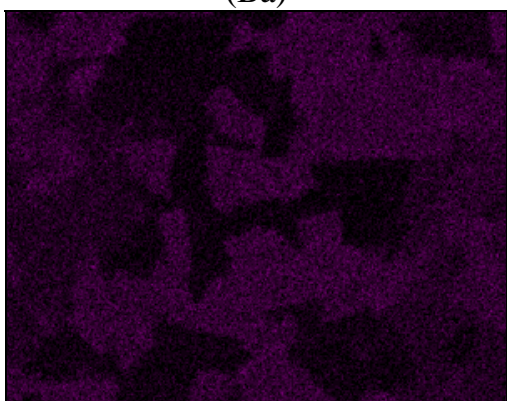

$(\mathrm{Gd})$

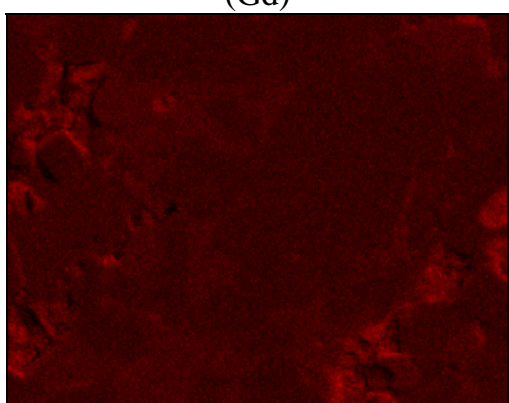

(O)

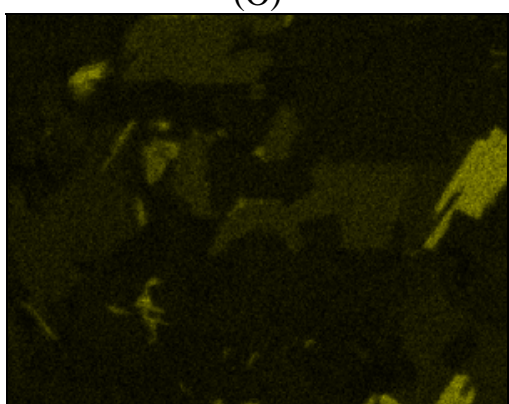

(Zr)

Figure 3-6. EDS Mapping for Select Elements in Composition CSLNTM-10 Fabricated by Melting and Crystallizing.

A very small sample of the composition CSLNTM-10 material was extracted using Focused Ion Beam (FIB) milling with the intent of observing the dissolution behavior of individual phases within the multiphase waste form after immersion in $90{ }^{\circ} \mathrm{C}$ deionized water for seven days. The results presented here are preliminary since the experimental methodology needs to be further refined. However, the images below should provide some insight into the potential utility of this technique. Figure 3-7a is a micrograph of the CSLNTM-10 sample prepared by FIB milling. The left side of the sample is affixed to 
a copper support grid. Excess material left from the milling process is adhered to the lower right corner of the sample. Although not clearly defined, the sample contains a small number of individual grains. Future samples will be further thinned with the ion beam to allow for better imaging of the individual grains.

Figure 3-7b is a micrograph of the same sample after leaching in a sealed container of deionized water for 7 days at $90{ }^{\circ} \mathrm{C}$. The sample is largely unchanged, with the exception of some small particles now present on the surface. These particles are also visible on the copper support grid. There is some foreshortening of the image in Figure 3-7b caused by tilting of the sample, which gives the false appearance that the sample is smaller after leaching.

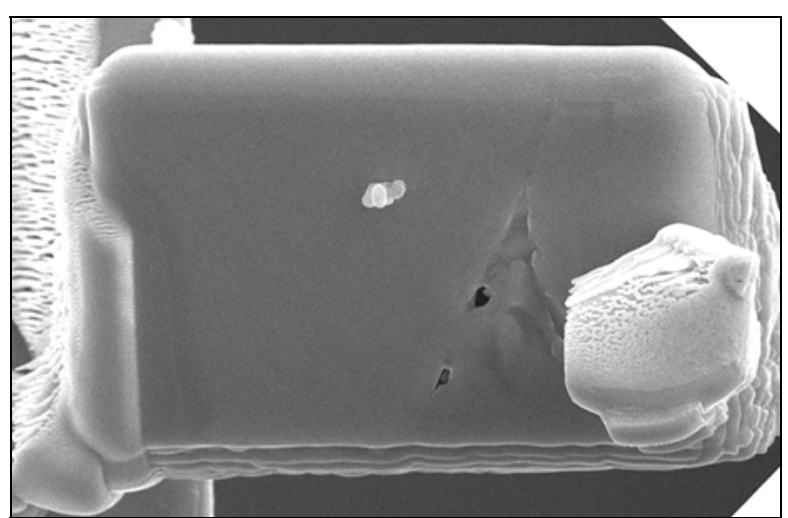

(a)

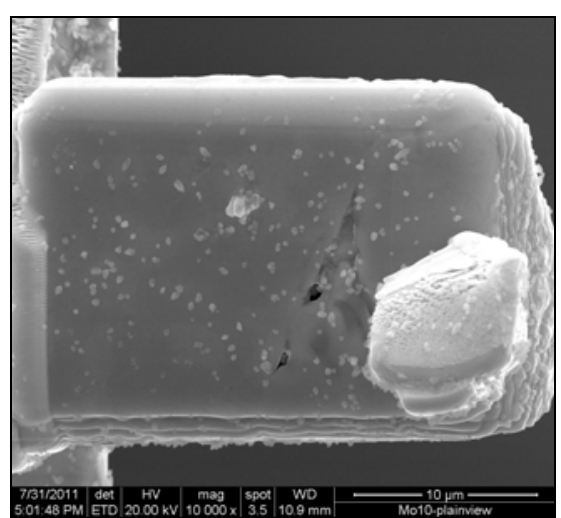

(b)

Figure 3-7. Secondary Electron Micrographs of a Sample of Composition CSLNTM-10 Prepared by FIB Milling Before (a) and After (b) Leach in Water.

EDX mapping was recorded for the sample both before and after leaching. Figure 3-8 shows the EDS maps for the sample prior to leaching. $\mathrm{Ba}, \mathrm{Ca}, \mathrm{Ce}, \mathrm{Nd}$, and $\mathrm{Ti}$ are present in the large grain at the center of the sample. $\mathrm{Ga}$ and Pt are introduced as part of the FIB preparation process. Excess Pt in the sample will be reduced in future work through finer scale (lower beam current) ion milling. Figure 3-9 shows the EDS maps for the same sample after leaching. There are no obvious changes in the partitioning of the elements. The small particles on the surface of the sample appear to be Mo. These may have originated from the Mo sample holder used in the SEM. Again, these results are preliminary at this point and are reported here only to provide some insight into the potential utility of this technique. Future work will involve milling larger and thinner samples to better observe differences in dissolution behavior among the individual phases within the multiphase ceramic waste forms. 


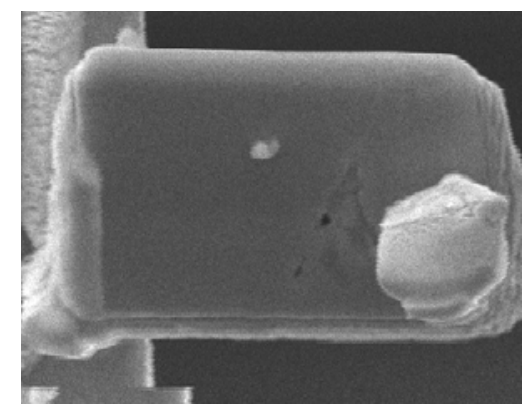

(Secondary electron image)

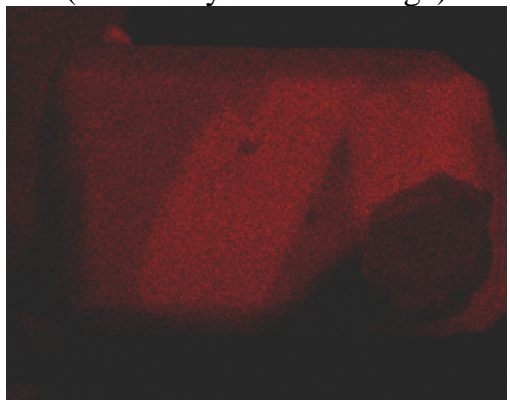

(Ca)

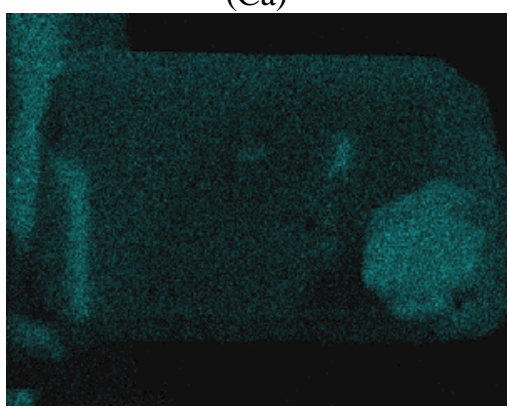

(Mo)

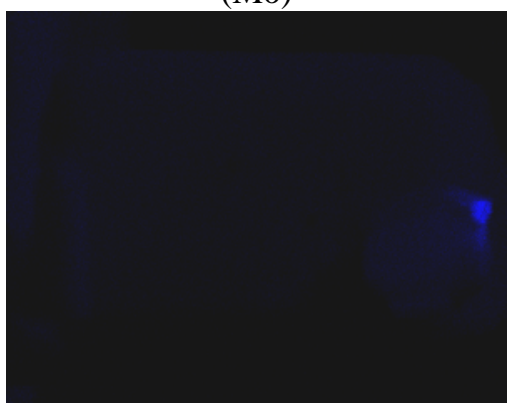

(Sr)

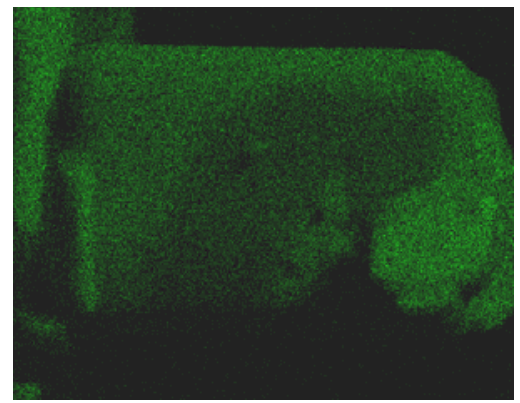

(Al)

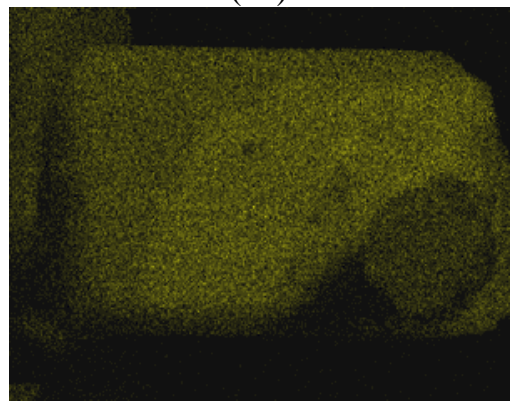

(Ce)

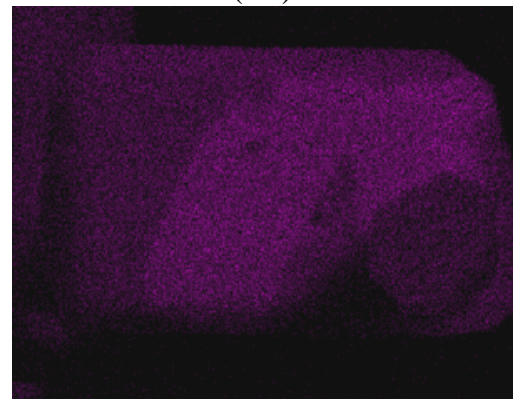

(Nd)

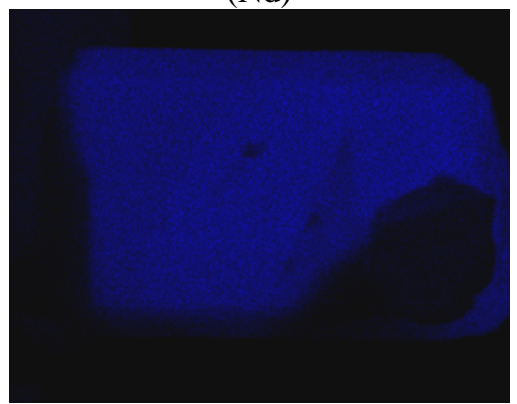

(Ti)

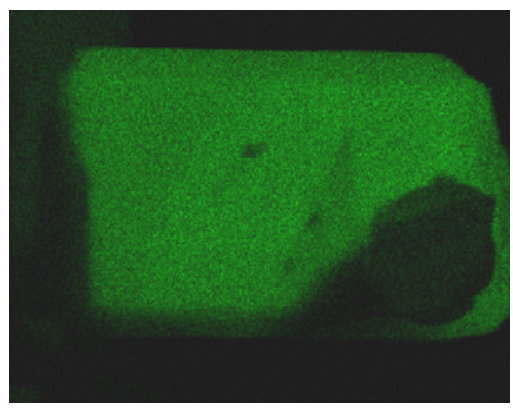

$(\mathrm{Ba})$

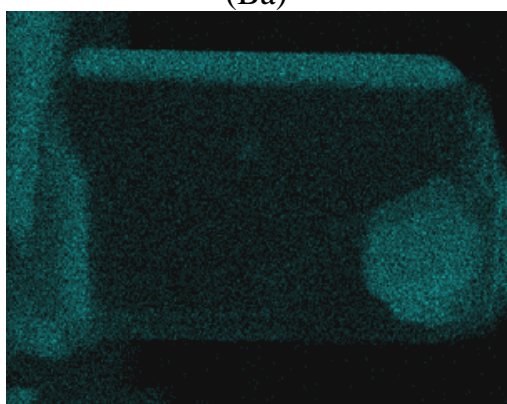

(Ga)

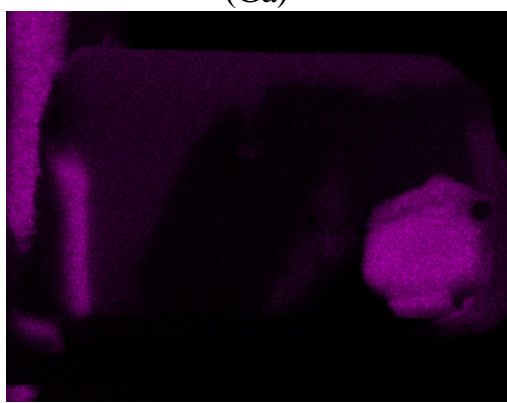

$(\mathrm{Pt})$

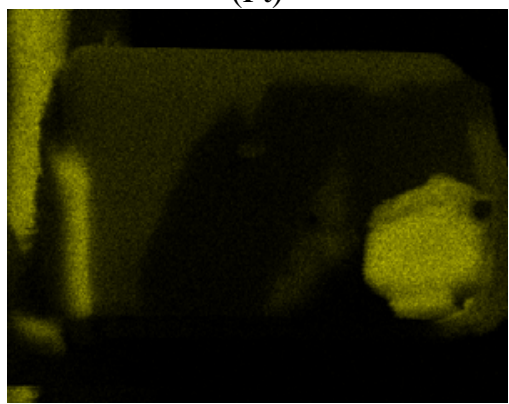

(Zr)

Figure 3-8. EDS Mapping for Select Elements in a FIB Milled Sample of Composition CSLNTM-10 Fabricated by Melting and Crystallizing, Prior to Leaching in Water. 


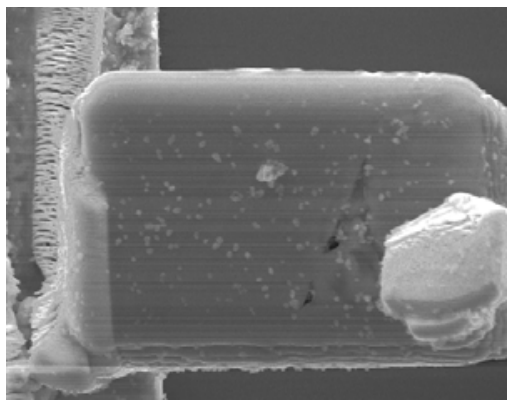

(Secondary electron image)

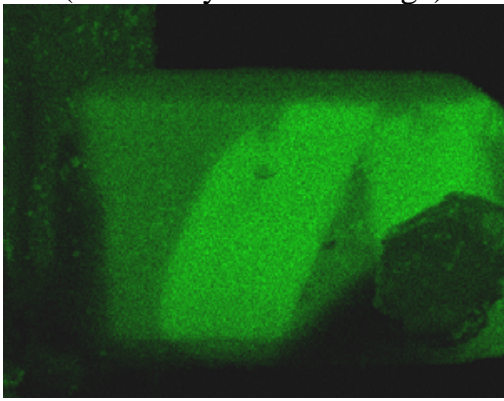

(Ca)

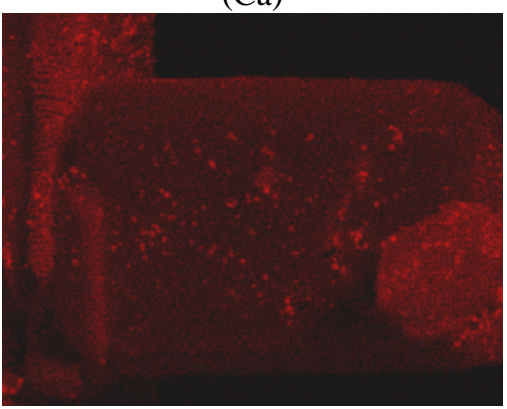

(Mo)

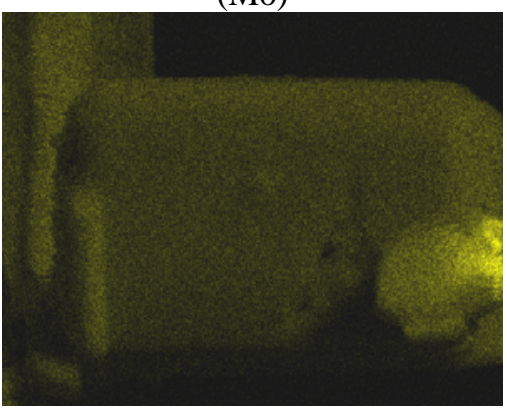

(Sr)

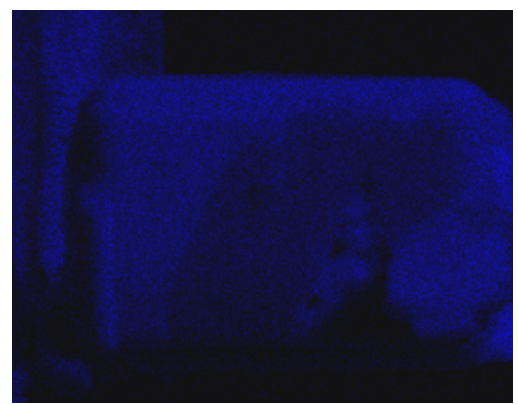

(Al)

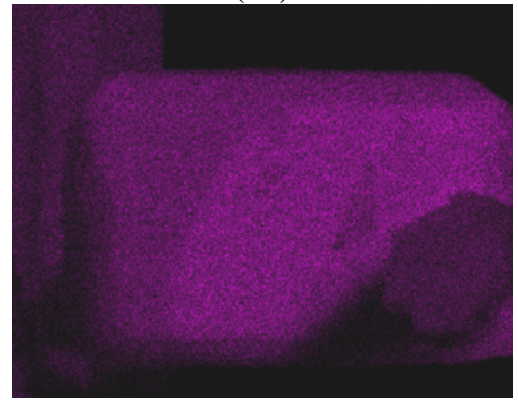

(Ce)

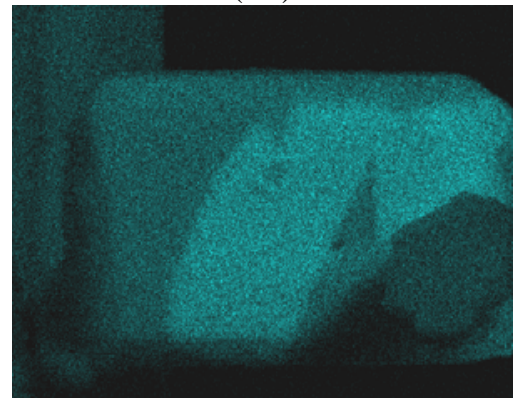

$(\mathrm{Nd})$

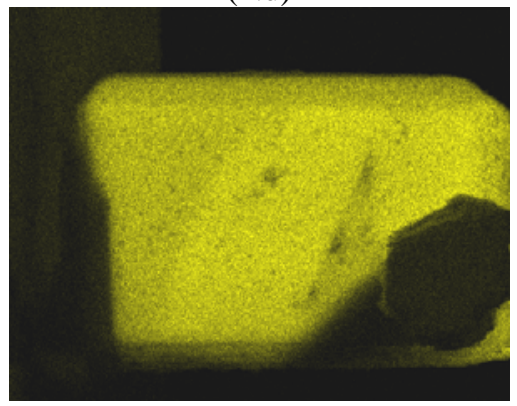

(Ti)

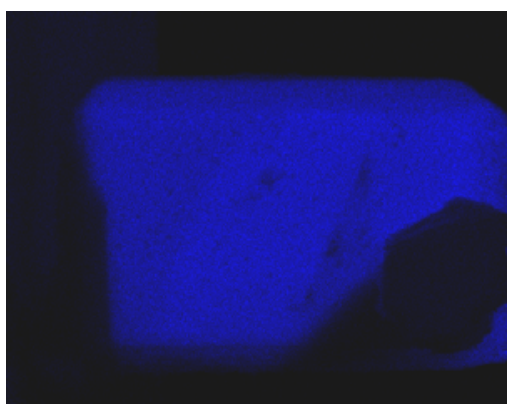

$(\mathrm{Ba})$

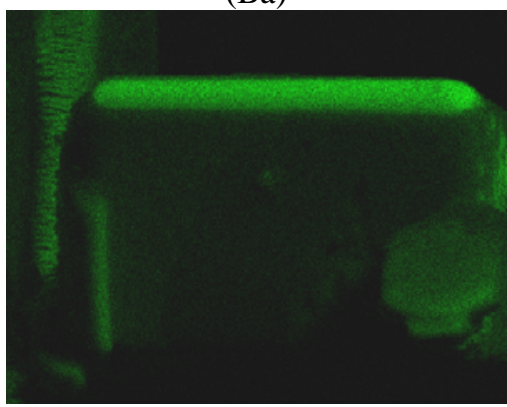

(Ga)

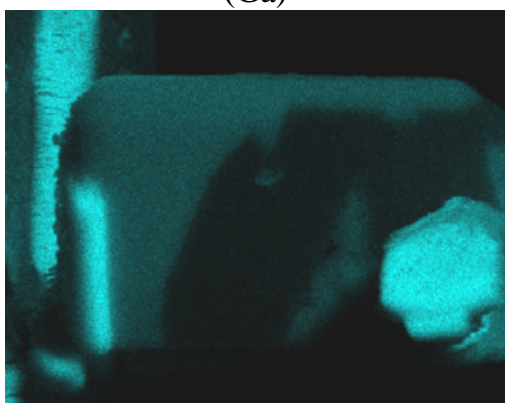

$(\mathrm{Pt})$

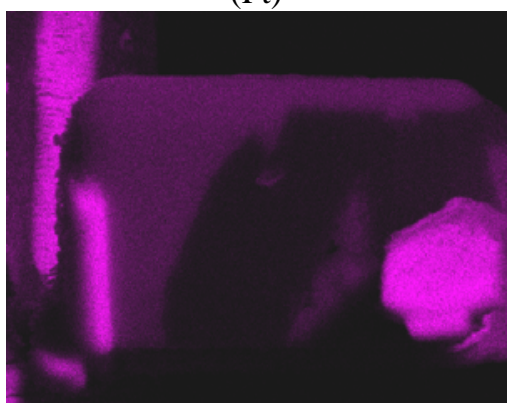

(Zr)

Figure 3-9. EDS Mapping for Select Elements in a FIB Milled Sample of Composition CSLNTM-10 Fabricated by Melting and Crystallizing, After Leaching in Water.

\subsection{Crystalline Phase Assemblages}

XRD data for the FY11 CS/LN/TM High Mo compositions prepared via the press and sinter and melt and crystallization fabrication methods are summarized in Table 3-5. Similar to studies initiated in FY10, the XRD spectra were complex, indicating multiple crystalline phases present. No broad, low angle peaks indicative of amorphous or glassy phase content were observed. Also similar to FY10 studies, the types of phases formed were dependent on the type of fabrication method used. For instance, a pyrochlore phase 
of the form (Gd,Sm,Nd) $\mathrm{Ti}_{2} \mathrm{O}_{7}$ formed at lower temperatures used in the press and sinter process, while perovskite ( $\mathrm{La}, \mathrm{Ce}, \mathrm{Nd}, \mathrm{Ca}, \mathrm{Sr}) \mathrm{TiO}_{3}$ was the dominant titanate phase when the higher temperature melt process was used. A hollandite phase $(\mathrm{Ba}, \mathrm{Cs}, \mathrm{Rb}) \mathrm{Al}_{2} \mathrm{Ti}_{5} \mathrm{O}_{14}$ and un-reacted $\mathrm{TiO}_{2}$ was observed to be present in all samples, independent of processing method. Crystalline zirconium containing phases $\mathrm{CaZrTi}_{2} \mathrm{O}_{7}$ (zirconolite) and (Ca,Nd,Al) $)_{1-\mathrm{x}} \mathrm{Zr}_{\mathrm{x}} \mathrm{O}_{2}$ were detected in the melt and crystallize samples but were not found in the press and sinter samples. Due to a focus on the melt and crystallize process for potential melter demonstration runs, press and sinter samples of FY11 compositions were not investigated by SEM/EDS. From experience with similar compositions in FY10, it is expected that the fine grained press and sinter samples would contain some $\mathrm{Ca}, \mathrm{Zr}$, and $\mathrm{O}$ association. The complex and often overlapping XRD patterns of these phase assemblages precludes a definite conclusion at present.

The molybdenum containing phase powellite $(\mathrm{Ba}, \mathrm{Ca}) \mathrm{MoO}_{4}$ was only observed by $\mathrm{XRD}$ in the CSLNTM-10 sample processed by the melt and crystallize process. Again, multiple peaks from related crystalline phases may obscure the identification of the powellite in these materials. A more complete picture of phase formation and elemental partitioning can be gained by comparison of XRD and $\mathrm{SEM} / \mathrm{EDS}$ mapping data for select samples. The strong $\mathrm{Zr}$ signal seen in a few grains un-associated with any other elements corresponds to a principally $\mathrm{ZrO}_{2}$ phase $(\mathrm{Ca}, \mathrm{Nd}, \mathrm{Al})_{1-\mathrm{x}} \mathrm{Zr}_{\mathrm{x}} \mathrm{O}_{2}$. The powellite phase is seen to be $\mathrm{Ba}$ rich and $\mathrm{Ca}$ poor, and includes further substitution of $\mathrm{Ce}, \mathrm{Nd}, \mathrm{Gd}, \mathrm{Sr}, \mathrm{Ti}$ and $\mathrm{Zr}$. In summary, the targeted crystalline phases of pyrochlore, perovskite, hollandite, zirconolite, and powellite were formed by both the press and sinter and the melt and crystallize processing methods. The following section will compare phase formation in the melt and crystallize process across a broad composition range. 
Table 3-5. Summary of XRD Data for Ceramic Waste Forms Prepared by Press and Sinter, and Melt and Crystallization.

\begin{tabular}{|c|c|c|c|c|c|c|}
\hline \multirow{2}{*}{ Phases } & \multicolumn{3}{|c|}{ Press and Sinter } & \multicolumn{3}{c|}{ Melt and Crystallize } \\
\cline { 2 - 7 } & CSLNTM-10 & CSLNTM-11 & CSLNTM-12 & CSLNTM-10 & CSLNTM-11 & CSLNTM-12 \\
\hline $\begin{array}{c}\text { (Ba,Ca) } \mathrm{MoO}_{4} \\
\text { powellite }\end{array}$ & - & - & - & $\mathbf{X}$ & - & - \\
\hline $\begin{array}{c}(\mathrm{Gd}, \mathrm{Sm}, \mathrm{Nd}) \mathrm{Ti}_{2} \mathrm{O}_{7} \\
\text { pyrochlore }\end{array}$ & $\mathbf{X}$ & $\mathbf{X}$ & $\mathbf{X}$ & - & - & - \\
\hline $\begin{array}{c}\mathrm{CaZrTi} \mathrm{O}_{7} \\
\text { zirconolite }\end{array}$ & - & - & - & $\mathbf{X}$ & $\mathbf{X}$ & $\mathbf{X}$ \\
\hline$(\mathrm{Ca}, \mathrm{Nd}, \mathrm{Al})_{1-\mathrm{x}} \mathrm{Zr}_{\mathrm{x}} \mathrm{O}_{2}$ & - & - & - & $\mathbf{X}$ & - & - \\
\hline $\begin{array}{c}(\mathrm{Ba}, \mathrm{Cs}, \mathrm{Rb}) \mathrm{Al}_{2} \mathrm{Ti}_{5} \mathrm{O}_{14} \\
\text { hollandite }\end{array}$ & $\mathbf{X}$ & $\mathbf{X}$ & $\mathbf{X}$ & $\mathbf{X}$ & $\mathbf{X}$ & $\mathbf{X}$ \\
\hline $\begin{array}{c}(\mathrm{La}, \mathrm{Ce}, \mathrm{Nd}, \mathrm{Ca}, \mathrm{Ba}, \mathrm{Sr}) \mathrm{TiO}_{3} \\
\text { perovskite }\end{array}$ & $\mathbf{X}$ & $\mathbf{X}$ & $\mathbf{X}$ & $\mathbf{X}$ & $\mathbf{X}$ & $\mathbf{X}$ \\
\hline $\begin{array}{c}\mathrm{TiO}_{2} \text { un-reacted } \\
\mathrm{Al}_{2} \mathrm{O}_{3} \text { un-reacted }\end{array}$ & $\mathbf{X}$ & $\mathbf{X}$ & $\mathbf{X}$ & $\mathbf{X}$ & $\mathbf{X}$ & $\mathbf{X}$ \\
\hline
\end{tabular}


XRD data for the FY10 and FY11 CS/LN/TM High Mo compositions prepared via the melt and crystallize process are depicted in Table 3-6. The compositional range spans from $\mathrm{Al}_{2} \mathrm{O}_{3}$ rich additions in CSLNTM-02 and -04, reduced $\mathrm{Al}_{2} \mathrm{O}_{3}$ content and increased $\mathrm{CaO}$ additions in CSLNTM-06 through -09, reduced $\mathrm{CaO}$ and excess $\mathrm{TiO}_{2}$ content in CSLNTM-10 with 50\% waste loading, to maintaining constant $\mathrm{Al}_{2} \mathrm{O}_{3}: \mathrm{TiO}_{2}$ and $\mathrm{Al}_{2} \mathrm{O}_{3}: \mathrm{CaO}$ ratios while decreasing waste loading from 40 to $30 \%$ in CSLNTM- 11 and -12 .

The powellite phase, primarily $\mathrm{BaMoO}_{4}$, was observed to be the dominant molybdenum containing phase and formed across a wide range of compositions. This phase was not detected by XRD analysis in CSLNTM-11 and -12, however the lower waste loadings in these specimens may have led to a reduced volume fraction and additional difficulty in identifying the peaks associated with this phase within the multi-phase system. Additional characterization via SEM and EDS is needed to confirm the association of these elements in these samples. Titanium based phases such as perovskite and pyrochlore formed across the compositional spectrum. In general, the $\mathrm{Al}_{2} \mathrm{O}_{3}$ rich compositions resulted in pyrochlore phase formation, while $\mathrm{TiO}_{2}$ rich compositions resulted in perovskite phase formation; however several compositions showed both perovskite and pyrochlore phases present (CSLNTM-02 and -04). Phases exhibiting an association of $\mathrm{Ca}$ and $\mathrm{Zr}$, such as zirconolite $\mathrm{CaZrTi}_{2} \mathrm{O}_{7}$ and $(\mathrm{Ca}, \mathrm{Nd}, \mathrm{Al})_{1-\mathrm{x}} \mathrm{Zr}_{\mathrm{x}} \mathrm{O}_{2}$, were found to form across the compositional spectrum. As would be expected, the $\mathrm{TiO}_{2}$ rich compositions (CSLNTM-10 through -12) formed the zirconolite phase.

Although many of the phases formed were similar across the wide compositional range studied, there were some important differences including the formation of aluminum titanate phases. Hollandite is the proposed ceramic host for Cs, which is difficult to immobilize due to its high volatility at elevated temperature, ability to form water soluble compounds, and potential for long term release during storage. Hollandite phases were detected by XRD analysis in several compositions including CSLNTM-06, -08, -10, and -11. In addition, the association of Cs and Al was confirmed with SEM/EDS analysis on the CSLNTM-06 sample. However, several $\mathrm{Al}_{2} \mathrm{O}_{3}$ rich compositions such as CSLNTM-02, and -04 did not show evidence of hollandite peaks and did not show a strong association of Cs with any other element by SEM/EDS analysis. Therefore, it currently appears that Cs is incorporated into different crystalline phases depending on the composition of the waste forms fabricated by the melt and crystallize process employed in this study.

A single composition, CSLNTM-11, was chosen for an evaluation of crystalline phase formation versus melt processing conditions. As described earlier, samples of this composition were melted at $1500{ }^{\circ} \mathrm{C}$ for 1 hour and cooled by furnace cooling (nominally $10^{\circ} \mathrm{C} /$ minute), as well as controlled cooling rates of $5{ }^{\circ} \mathrm{C}$ /minute and $1^{\circ} \mathrm{C} /$ minute. XRD analysis of these samples revealed that hollandite, perovskite, zirconolite, and residual $\mathrm{TiO}_{2}$ phases formed independently of the cooling rate, demonstrating the robust nature of this process for crystalline phase development. 
Table 3-6. Summary of FY10 and FY11 XRD Data for CS/LN/TM High Mo Waste Forms Prepared by a Melt and Crystallize Process.

\begin{tabular}{|c|c|c|c|c|c|c|c|c|}
\hline \multirow{2}{*}{ Phases } & \multicolumn{8}{|c|}{ Melt and Crystallize } \\
\hline & CSLNTM-02 & CSLNTM-04 & CSLNTM-06 & CSLNTM-08 & CSLNTM-09 & CSLNTM-10 & CSLNTM-11 & CSLNTM-12 \\
\hline $\begin{array}{l}(\mathrm{Ba}, \mathrm{Ca}) \mathrm{MoO}_{4} \\
\text { powellite }\end{array}$ & $\mathrm{X}$ & $\mathrm{X}$ & $\mathrm{X}$ & $\mathbf{X}$ & $\mathbf{X}$ & $\mathrm{X}$ & - & - \\
\hline $\begin{array}{l}(\mathrm{Gd}, \mathrm{Sm}, \mathrm{Nd}) \mathrm{Ti}_{2} \mathrm{O}_{7} \\
\text { pyrochlore }\end{array}$ & $\mathrm{X}$ & $\mathrm{X}$ & $\mathrm{X}$ & $\mathbf{X}$ & - & - & - & - \\
\hline $\begin{array}{l}\mathrm{CaZrTi}_{2} \mathrm{O}_{7} \\
\text { zirconolite }\end{array}$ & $X$ & - & - & - & - & $\mathrm{X}$ & $\mathbf{x}$ & $x$ \\
\hline$(\mathrm{Ca}, \mathrm{Nd}, \mathrm{Al})_{1-\mathrm{x}} \mathrm{Zr}_{\mathrm{x}} \mathrm{O}_{2}$ & - & - & $x$ & $x$ & $x$ & $x$ & - & - \\
\hline $\begin{array}{c}(\mathrm{Ba}, \mathrm{Cs}, \mathrm{Rb}) \mathrm{Al}_{2} \mathrm{Ti}_{5} \mathrm{O}_{14} \\
\text { hollandite }\end{array}$ & - & - & $\mathrm{X}$ & $\mathbf{X}$ & & $\mathbf{X}$ & $\mathbf{X}$ & $\mathbf{X}$ \\
\hline $\begin{array}{c}(\mathrm{La}, \mathrm{Ce}, \mathrm{Nd}, \mathrm{Ca}, \mathrm{Ba}, \mathrm{Sr}) \mathrm{TiO}_{3} \\
\text { perovskite }\end{array}$ & $\mathrm{X}$ & $\mathrm{X}$ & - & - & $\mathbf{X}$ & $\mathbf{X}$ & $\mathbf{X}$ & $\mathbf{X}$ \\
\hline $\mathrm{TiO}_{2}$ un-reacted & - & - & - & - & - & $\mathbf{x}$ & $x$ & $x$ \\
\hline $\mathrm{Al}_{2} \mathrm{O}_{3}$ un-reacted & $x$ & $\mathrm{x}$ & - & - & - & - & - & - \\
\hline
\end{tabular}


In order to study elemental partitioning and behavior of individual phases in a multi-phase assembly, several single phase compositions were synthesized and characterized. Figure 3-10 displays the XRD spectra comparing powders calcined at $1000^{\circ} \mathrm{C}$ for four hours to a sample melted at $1550{ }^{\circ} \mathrm{C}$ for 20 minutes. The powders were stoichiometric, ball-milled mixtures of $\mathrm{BaCO}_{3}, \mathrm{Al}_{2} \mathrm{O}_{3}$, and $\mathrm{TiO}_{2}$ targeting a $\mathrm{BaAl}_{2} \mathrm{Ti}_{6} \mathrm{O}_{16}$ single phase. The calcined sample revealed multiple crystalline phases of $\mathrm{TiO}_{2}, \mathrm{Al}_{2} \mathrm{O}_{3}$, $\mathrm{BaTi}_{4} \mathrm{O}_{9}, \mathrm{BaTiO}_{3}$, and $\mathrm{BaTi}_{5} \mathrm{Al}_{2} \mathrm{O}_{14}$, but not the targeted hollandite phase. The sample processed by melting and crystallizing revealed a majority of the hollandite type phase $\mathrm{Ba}_{1.23} \mathrm{Al}_{2.46} \mathrm{Ti}_{5.54} \mathrm{O}_{16}$, along with $\mathrm{TiO}_{2}$ and $\mathrm{Al}_{2} \mathrm{TiO}_{5}$ phases. In hollandite forms previously studied for nuclear waste incorporation, the $\mathrm{A}$ position is occupied by $\mathrm{Cs} / \mathrm{Rb}$ and $\mathrm{Ba}$, the $\mathrm{B}$ position by $\mathrm{Al}$ and $\mathrm{Ti}^{+3}$, and the $\mathrm{C}$ position by $\mathrm{Ti}^{+4}$ resulting in the general formula $\left(\mathrm{Ba}_{\mathrm{x}} \mathrm{Cs}_{\mathrm{y}}\right)(\mathrm{Ti}, \mathrm{Al})^{+3}{ }_{2 \mathrm{x}+\mathrm{y}}\left(\mathrm{Ti}^{+4}{ }_{8-2 \mathrm{x}-\mathrm{y}}\right) \mathrm{O}_{16}{ }^{16}$ The presence of the multivalent $\mathrm{Ti}$ species required for stable phase formation may pose a problem during processing; the Ti valence is also affected by charge compensation needed by different Cs/Ba ratios. Kesson demonstrated the use of Ti metal and hot pressing techniques to control the reduction/oxidation (redox) conditions for phase formation in the range of $1250{ }^{\circ} \mathrm{C} .{ }^{17}$ Later, Carter and Vance showed that Ba and Cs hollandites could be made with hot pressing using the graphite die alone to maintain the desired reduction/oxidation state. Recently, different titanate hollandite materials with the formula of $\left(\mathrm{Ba}_{\mathrm{x}} \mathrm{Cs}_{\mathrm{y}}\right)(\mathrm{M}, \mathrm{Ti})_{8} \mathrm{O}_{16}$ with $\mathrm{M}=\mathrm{Mn}^{+3}, \mathrm{Fe}^{+3}, \mathrm{Ga}^{+3}, \mathrm{Cr}^{+3}, \mathrm{Sc}^{+3}$, $\mathrm{Mg}^{+2}$ containing mixtures of divalent and trivalent cations have also been fabricated by solution mixtures of alkoxide precursors followed by pressure-less sintering in air or $\operatorname{argon}^{18}$. The results of the present study indicate that pressureless sintering of oxides in air at temperatures near $1000{ }^{\circ} \mathrm{C}$ is insufficient for hollandite phase formation; however, elevated temperatures near the melting point of $1500^{\circ} \mathrm{C}$ produce samples with a large amount of the desired hollandite phase.

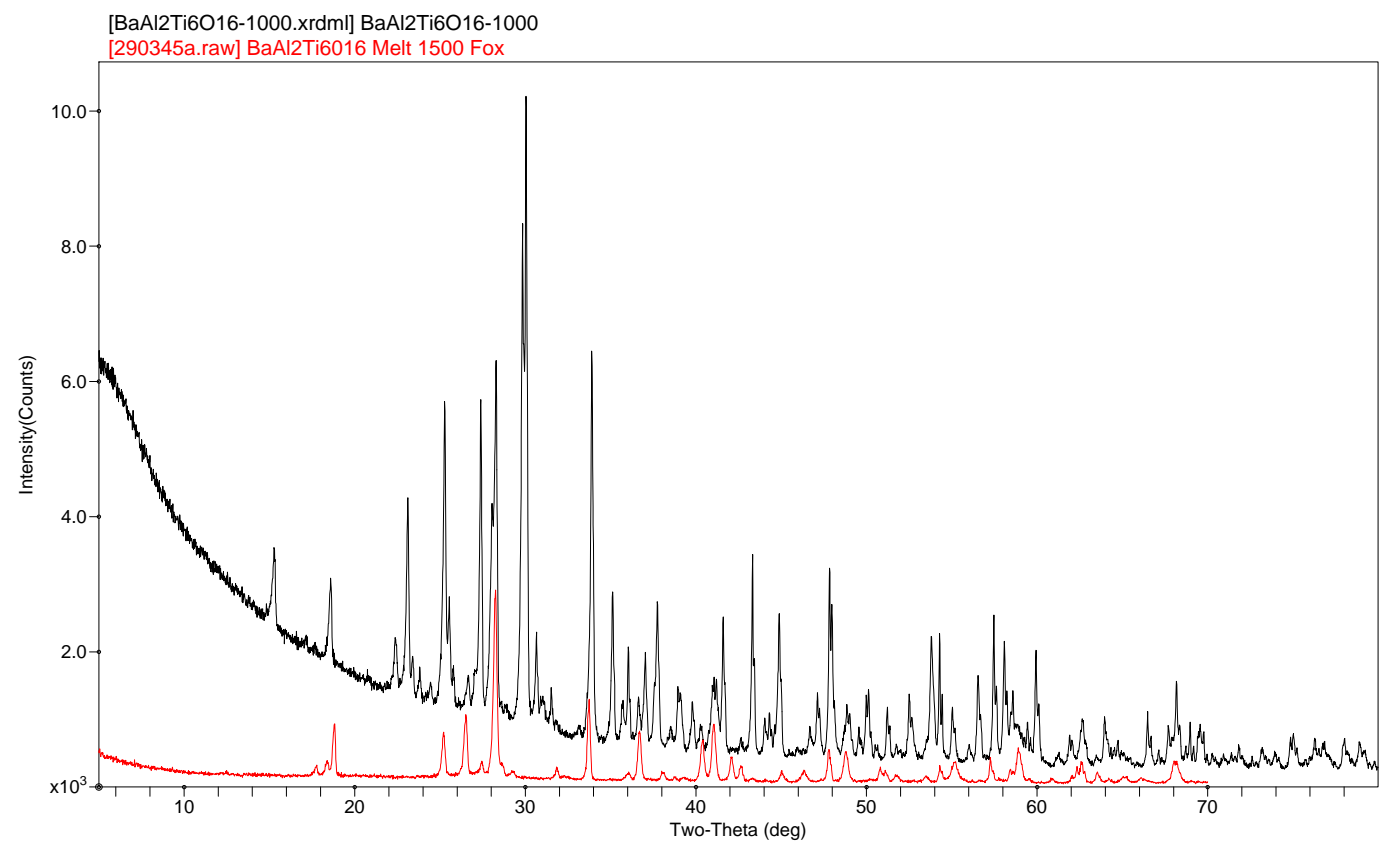

Figure 3-10. XRD Patterns of Calcined Powders Heated to $1000{ }^{\circ} \mathrm{C}$ (black line) and a Melted and Crystallized Sample (red line) Targeting $\mathrm{BaAl}_{2} \mathrm{Ti}_{6} \mathrm{O}_{16}$ Single Phase Formation.

Figure 3-11 displays the XRD spectrum of a stoichiometric blend of $\mathrm{CaCO}_{3}$, and $\mathrm{MoO}_{3}$ oxide powders targeting the $\mathrm{CaMoO}_{4}$ powellite phase that was melted at $1500{ }^{\circ} \mathrm{C}$ for 20 minutes. A single phase of powellite was observed in both $\mathrm{CaMoO}_{4}$ and $\mathrm{BaMoO}_{4}$ phase systems produced by the melt and crystallize method. Powellite phase $\mathrm{CaMoO}_{4}$ and $\mathrm{BaMoO}_{4}$ were also observed in calcined powders in the temperature range of $900-1100^{\circ} \mathrm{C}$. A Transmission Electron Microscope (TEM) image of $\mathrm{CaMoO}_{4}$ 
produced by the melt and crystallize process is displayed in Figure 3-12. The single phase nature of the sample is confirmed by the Selected Area Diffraction pattern and EDS spectrum. These results indicate that $\mathrm{BaMoO}_{4}$ and $\mathrm{CaMoO}_{4}$ readily formed by both the press and sinter and the melt and crystallize processing methods.

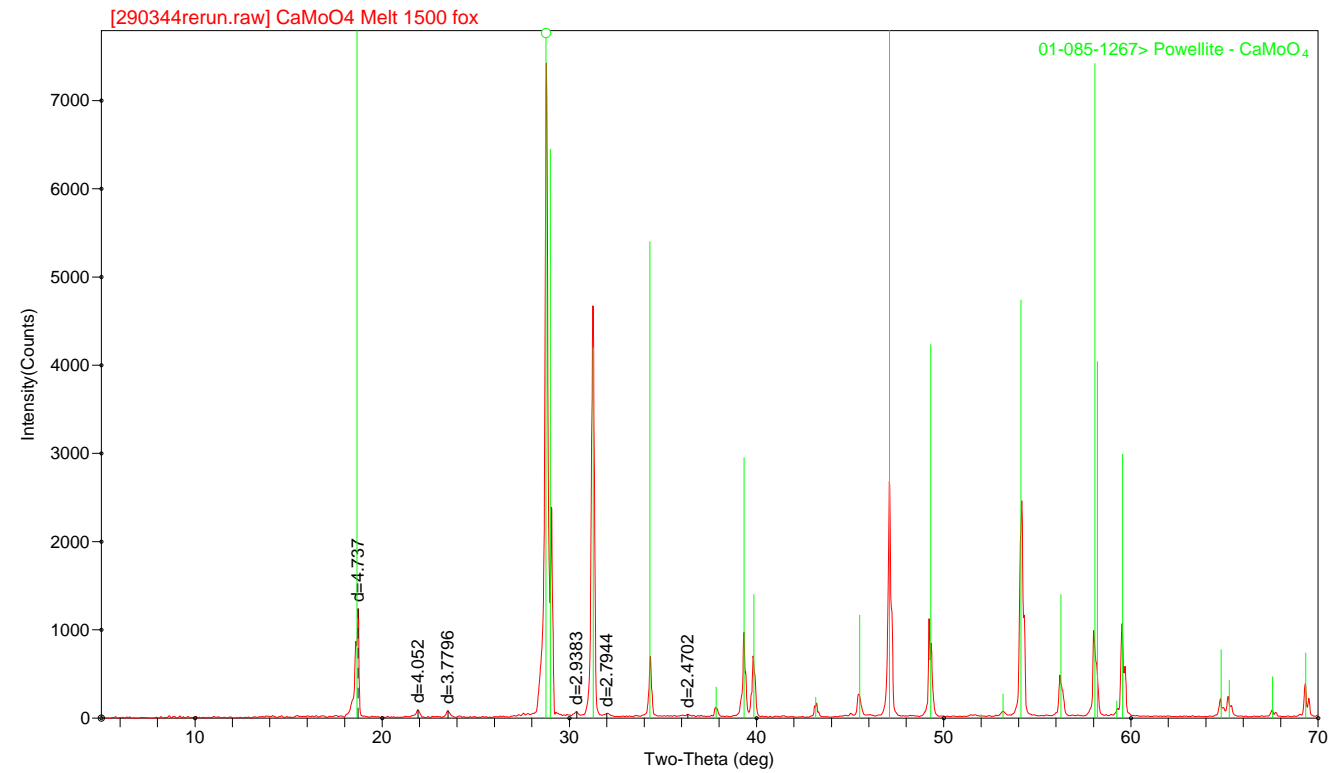

Figure 3-11. $\mathrm{XRD}$ of melt and crystallize $1500{ }^{\circ} \mathrm{C}$ process targeting $\mathrm{CaMoO}_{4}$ single phase 


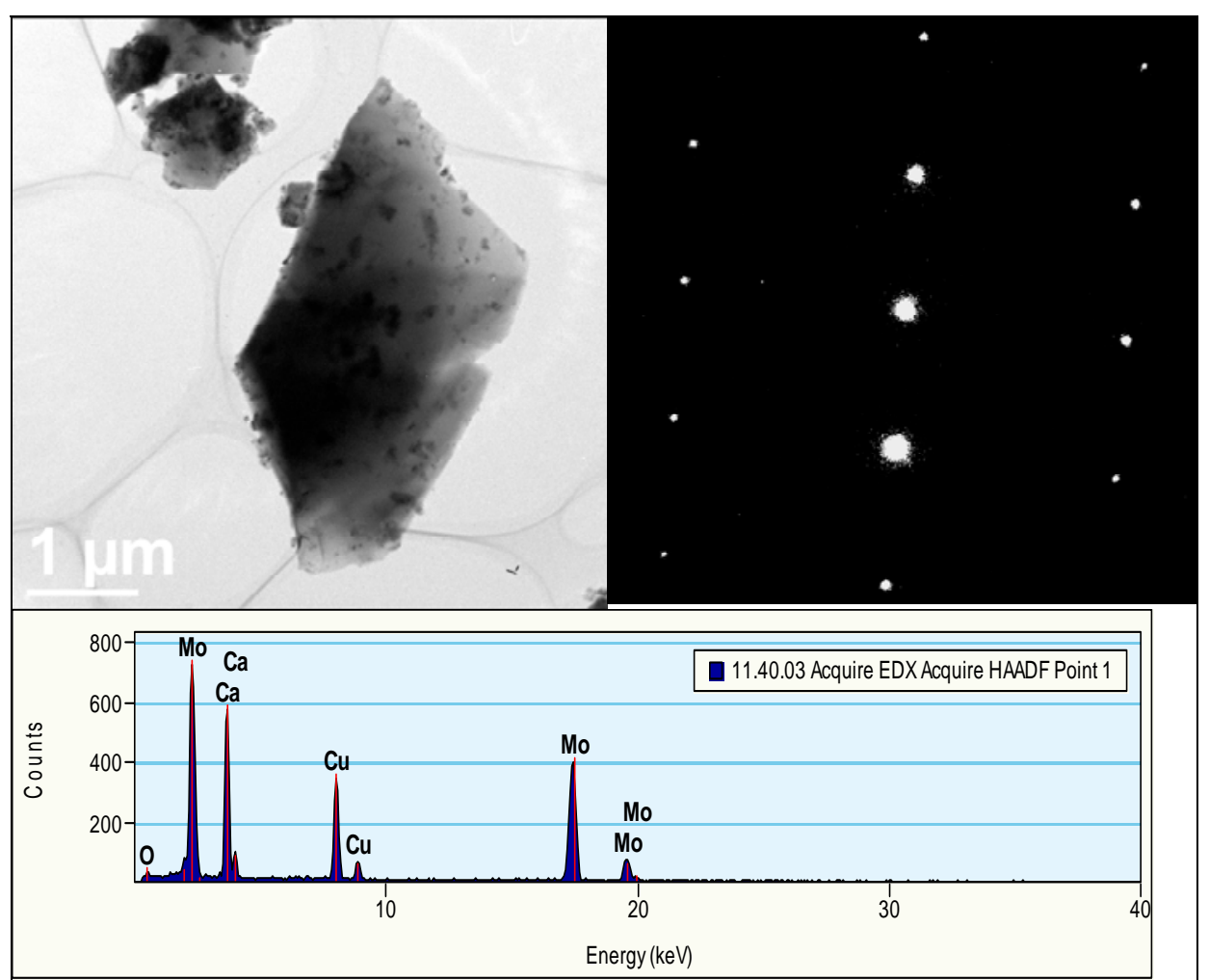

Figure 3-12. TEM Image of a $\mathrm{CaMoO}_{4}$ Sample Produced by Melting and 'Crystallizing, Along with a Selected Area Electron Diffraction Image and an EDS spectrum.

\subsection{Chemical Durability}

BET surface area measurements were completed for several samples in support of the PCT chemical durability measurements. These data are given in Table 3-7, and were used to calculate surface area to volume ratios for each sample subjected to the PCT. 
Table 3-7. Results of BET Surface Area Measurements for Those Samples Included in the PCTs.

\begin{tabular}{|c|c|c|}
\hline $\begin{array}{c}\text { PCT } \\
\text { Set }\end{array}$ & Composition & $\begin{array}{c}\text { BET Surface Area } \\
\left(\mathrm{m}^{2} / \mathrm{g}\right)\end{array}$ \\
\hline \multirow{7}{*}{1} & CSLNTM-02 & 0.2684 \\
\hline & CSLNTM-06 & 0.2109 \\
\hline & $\begin{array}{c}\text { CSLNTM-11, } \\
1150^{\circ} \mathrm{C} \text { for } 1 \mathrm{hr} \text {, furnace cooled }\end{array}$ & 0.1244 \\
\hline & $\begin{array}{c}\text { CSLNTM-11, } \\
1150^{\circ} \mathrm{C} \text { for } 1 \mathrm{hr}, 5^{\circ} \mathrm{C} / \mathrm{min} \text { cooling }\end{array}$ & 0.1163 \\
\hline & $\begin{array}{c}\text { CSLNTM-11, } \\
1150^{\circ} \mathrm{C} \text { for } 1 \mathrm{hr}, 1^{\circ} \mathrm{C} / \mathrm{min} \text { cooling }\end{array}$ & 0.0967 \\
\hline & $\begin{array}{c}\text { CSLNTM-11, } \\
1150^{\circ} \mathrm{C} \text { for } 6 \mathrm{hr} \text {, furnace cooled }\end{array}$ & 0.0928 \\
\hline & $\begin{array}{c}\mathrm{Al}_{2} \mathrm{O}_{3} \text { reference standard } \\
(0.26+/-0.03)\end{array}$ & 0.2300 \\
\hline \multirow{7}{*}{2} & $\begin{array}{c}\text { CSLNTM-11 } \\
\text { pressed and sintered }\end{array}$ & 0.5171 \\
\hline & $\begin{array}{c}\text { CSLNTM-11 } \\
\text { calcined, } 1150^{\circ} \mathrm{C} \text { for } 1 \mathrm{hr} \text {, furnace cooled }\end{array}$ & 0.1547 \\
\hline & $\mathrm{CaMoO}_{4}$ & 0.1215 \\
\hline & $\mathrm{BaMoO}_{4}$ & 0.0920 \\
\hline & $\mathrm{BaAl}_{2} \mathrm{Ti}_{6} \mathrm{O}_{16}$ & 0.2681 \\
\hline & $\begin{array}{c}\text { CS/LN/TM High Mo, } \\
\text { calcined, simulated waste without additives }\end{array}$ & 1.4214 \\
\hline & $\begin{array}{c}\mathrm{Al}_{2} \mathrm{O}_{3} \text { reference standard } \\
(0.26+/-0.03)\end{array}$ & 0.2765 \\
\hline
\end{tabular}

The PCT was used to provide insight into the chemical durability of the waste forms fabricated by melting and crystallizing. The results can only be used as preliminary information since no benchmark materials exist for comparison. Relationships between the rates of leaching of elements in nonradioactive waste forms of this type have not been related to the rates of leaching of actual radionuclides under the PCT conditions. For example, the EA glass was developed as a benchmark for the PCT with borosilicate waste glasses. ${ }^{19}$ The leaching rate of boron in non-radioactive borosilicate glasses can be related to radionuclide release in actual high level waste glasses. No such benchmark composition is available for the aluminum and titanium-based ceramic waste forms in this study. However, the results can provide some measure of the ability of the ceramics to contain the simulated waste elements, and qualitative differences among the compositions studied can be identified.

The PCTs for the FY11 study were split into two sets as the samples were prepared. Results of the PCT for the first set of ceramic waste form samples are given in Table 3-8. The numbers of replicates tested for each composition are listed in the table and were dependent on the amount of material available for the test. The results for the ARM reference glass indicated that the PCT was performed within the control limits for that glass. ${ }^{20}$ There were no issues with the blanks from the vessel cleaning batches, and the results for one of the vessels were removed from the normalization calculation due to a water loss issue.

The PCT results in Table 3-8 show that the normalized release values for several of the elements measured were either very small or below the instrument detection limits. Elevated normalized release values were measured only for $\mathrm{Cs}$, Mo, and Rb. For these three elements, compositions CSLNTM-02 and CSLNTM-06 appear to have better chemical durability than composition CSLNTM-11. It is difficult to draw further conclusions from these data until a benchmark material is developed for the PCT with this 
type of waste form. In addition, the variable release rates of Cs, Mo, and Rb may be tied to both the elemental composition of single phases as well as the overall phase assemblage. From the analysis presented in Section 3.4, it was seen that CSLNTM-02 did not exhibit a hollandite phase and also did not display a strong association of Cs to other elements in the waste form; however, this composition has demonstrated some of the best Cs durability performance. It is for this reason that single phase investigations have focused on $\mathrm{Cs}$, Mo, and $\mathrm{Rb}$ containing phases consisting of hollandite and powellite.

Also shown in Table 3-8 are the PCT results for the CSLNTM-10 samples fabricated with differing heat treatments. Again, Cs, Mo, and Rb are the only elements with elevated normalized release values. Interpretation of these results is complicated by the fact that a large percentage of these elements volatilized in these samples since they were held for longer periods at high temperature (see Table 3-2). In general, the release rates of $\mathrm{Cs}, \mathrm{Mo}$, and $\mathrm{Rb}$ are much higher than those of the other elements in the ceramic and are likely a concern for these waste forms. 
Table 3-8. Results of the PCT for the First Set of Ceramic Waste Forms.

Normalized Release Values $\left(\mathrm{g} / \mathrm{m}^{2}\right)$ are Given for Several Elements.

\begin{tabular}{||c|c|c|c|c|c|c|c|c|c|c|c|}
\hline Composition & $\begin{array}{c}\text { Number of } \\
\text { Replicates }\end{array}$ & Ag & Al & $\mathbf{B a}$ & $\mathbf{C a}$ & $\mathbf{C s}$ & $\mathbf{M o}$ & $\mathbf{R b}$ & $\mathbf{S r}$ & $\mathbf{R h}$ & $\mathbf{R u}$ \\
\hline CSLNTM-02 & 2 & $\mathrm{~b} / \mathrm{d}$ & 0.00 & 0.00 & 0.00 & 2.88 & 0.38 & 2.61 & 0.01 & $\mathrm{~b} / \mathrm{d}$ & $\mathrm{b} / \mathrm{d}$ \\
\hline CSLNTM-06 & 4 & $\mathrm{~b} / \mathrm{d}$ & 0.03 & 0.01 & 0.00 & 3.34 & 0.87 & 2.66 & 0.02 & $\mathrm{~b} / \mathrm{d}$ & $\mathrm{b} / \mathrm{d}$ \\
\hline CSLNTM-11 & 3 & $\mathrm{~b} / \mathrm{d}$ & 0.06 & 0.03 & 0.01 & 9.62 & 2.00 & 7.02 & 0.05 & $\mathrm{~b} / \mathrm{d}$ & $\mathrm{b} / \mathrm{d}$ \\
\hline $\begin{array}{c}\text { CSLNTM-11, } \\
\text { cooled at 5 }{ }^{\circ} \mathrm{C} / \mathrm{min}\end{array}$ & 4 & $\mathrm{~b} / \mathrm{d}$ & 0.02 & 0.02 & 0.00 & 6.84 & 1.91 & 4.61 & 0.05 & $\mathrm{~b} / \mathrm{d}$ & $\mathrm{b} / \mathrm{d}$ \\
\hline $\begin{array}{c}\text { CSLNTM-11, } \\
\text { cooled at 1 }{ }^{\circ} \mathrm{C} / \mathrm{min}\end{array}$ & 4 & $\mathrm{~b} / \mathrm{d}$ & 0.02 & 0.01 & 0.00 & 52.97 & 0.85 & 3.09 & 0.04 & $\mathrm{~b} / \mathrm{d}$ & $\mathrm{b} / \mathrm{d}$ \\
\hline $\begin{array}{c}\text { CSLNTM-11, } \\
\text { melted for 6 hours }\end{array}$ & 4 & $\mathrm{~b} / \mathrm{d}$ & 0.01 & 0.03 & 0.01 & 6.82 & 0.20 & 1.28 & 0.09 & $\mathrm{~b} / \mathrm{d}$ & $\mathrm{b} / \mathrm{d}$ \\
\hline
\end{tabular}

Note: b/d indicates value was below the instrument detection limit. 
Results of the PCT for the second set of waste forms are given in Table 3-9. Four replicates were measured for each of these samples. The results for the ARM reference glass indicated that the second PCT was performed within the control limits for that glass. ${ }^{20}$ There were no issues with the blanks from the vessel cleaning batches, nor were there any water loss issues.

The CSLNTM-11 sample fabricated by pressing and sintering appears to have considerably lower normalized release values for Cs, Mo, and Rb as compared to the other CSLNTM-11 samples listed in Table 3-8. However, a review of Table 3-3 shows that there was considerable volatilization of these elements due to the 25 hour hold time at $1200{ }^{\circ} \mathrm{C}$. Therefore, these low normalized release values are due to the low concentrations of these elements actually present in this sample. The results for the CSLNTM-11 sample that was calcined followed by melting and crystallizing show no improvement in chemical durability as compared to the sample melted and crystallized without the calcination step (see Table 3-8).

The calcined, simulated CS/LN/TM High Mo waste without additives had relatively low normalized release values for $\mathrm{Cs}$, Mo, and $\mathrm{Rb}$. A review of the chemical composition data in Table 3-3 shows that these elements were well retained after the calcination. Therefore, it may be useful to further characterize the calcined material to determine what form these elements are in after calcining. This may provide insight into the most ideal phases to incorporate these elements to produce a durable waste form.

The PCT results for the single phase samples are also shown in Table 3-9. The powellite phases had very low normalized release values for $\mathrm{Ba}$, Ca, and Mo. The $\mathrm{BaAl}_{2} \mathrm{Ti}_{6} \mathrm{O}_{16}$ phase had very low normalized releases for $\mathrm{Al}$ and $\mathrm{Ba}$. These results indicate that the chemical durability of these individual phases was very good.

Again, it is difficult to draw further conclusions from these data until a benchmark material is developed for the PCT with this type of waste form. Further characterization should be performed to better understand the behavior of these materials in this durability test. The partitioning of Mo needs to be better understood since, while the durability of $\mathrm{BaMoO}_{4}$ and $\mathrm{CaMoO}_{4}$ was found to be very good, the normalized release values for Mo for the multiphase waste forms were relatively high. The partitioning of Cs also needs to be better understood to ensure that it is incorporated into a high durability phase. Further characterization of the calcined, simulated waste without additives, along with single phase studies on Cs containing crystal structures such as hollandite may provide important insight into how best to incorporate Cs in a durable manner. 
Table 3-9. Results of the PCT for the Second Set of Ceramic Waste Forms. Normalized Release Values $\left(\mathrm{g} / \mathrm{m}^{2}\right)$ are Given for Several Elements.

\begin{tabular}{|c|c|c|c|c|c|c|c|c|c|c|}
\hline "Composition & Ag & Al & Ba & Ca & Cs & Mo & $\mathbf{R b}$ & Sr & Ph & Ru \\
\hline $\begin{array}{l}\text { CSLNTM-11, pressed } \\
\text { and sintered at } 1200^{\circ} \mathrm{C} \\
\text { for } 25 \text { hours }\end{array}$ & 0.00 & $\mathrm{~b} / \mathrm{d}$ & 0.00 & 0.00 & 0.09 & 0.08 & 0.04 & 0.01 & 0.00 & 0.00 \\
\hline $\begin{array}{l}\text { CSLMTM-11, calcined } \\
\text { prior to melt and } \\
\text { crystallize } \\
\end{array}$ & 0.06 & 0.05 & 0.03 & 0.01 & 9.16 & 1.95 & 8.99 & 0.02 & 0.07 & 0.10 \\
\hline $\begin{array}{c}\text { Simulated CS/LN/TM } \\
\text { High Mo waste only, } \\
\text { calcined at } 950^{\circ} \mathrm{C}\end{array}$ & 0.01 & 0.03 & 0.00 & $\mathrm{~b} / \mathrm{d}$ & 0.63 & 0.03 & 0.66 & 0.00 & 0.00 & 0.00 \\
\hline $\mathrm{CaMoO}_{4}$ & - & - & - & $\mathrm{b} / \mathrm{d}$ & - & 0.01 & - & - & - & - \\
\hline $\mathrm{BaMoO}_{4}$ & - & - & 0.01 & - & - & 0.05 & - & - & - & - \\
\hline $\mathrm{BaAl}_{2} \mathrm{Ti}_{6} \mathrm{O}_{16}$ & - & 0.00 & 0.01 & - & - & - & - & - & - & - \\
\hline
\end{tabular}

Note: b/d indicates value was below the instrument detection limit 


\subsection{Radiation Damage Tolerance}

A sample of composition CSLNTM-06 fabricated by melting and crystallizing was subjected to a $2 \mathrm{MeV}$ proton beam with a fluence of $4 \times 10^{17}$ ions $/ \mathrm{cm}^{2}$ at room temperature to provide preliminary insight into the radiation damage tolerance of the ceramic waste form. These conditions are estimated to produce damage up to a depth of about $27 \mu \mathrm{m}$ within the material. The sample was evaluated by XRD before and after irradiation to identify any microstructural changes induced by the proton bombardment.

Figure 3-13 provides a comparison of XRD spectra of the surface of the sample of composition CSLNTM-06 obtained before and after the proton beam irradiation. There are some differences in relative intensities among the peaks in the spectra, but no changes in the phases present are apparent, indicating good radiation damage tolerance. The changes in relative intensity could be due to texturing since the spectra were collected from the polished surface of the sample, rather than crushed powders.

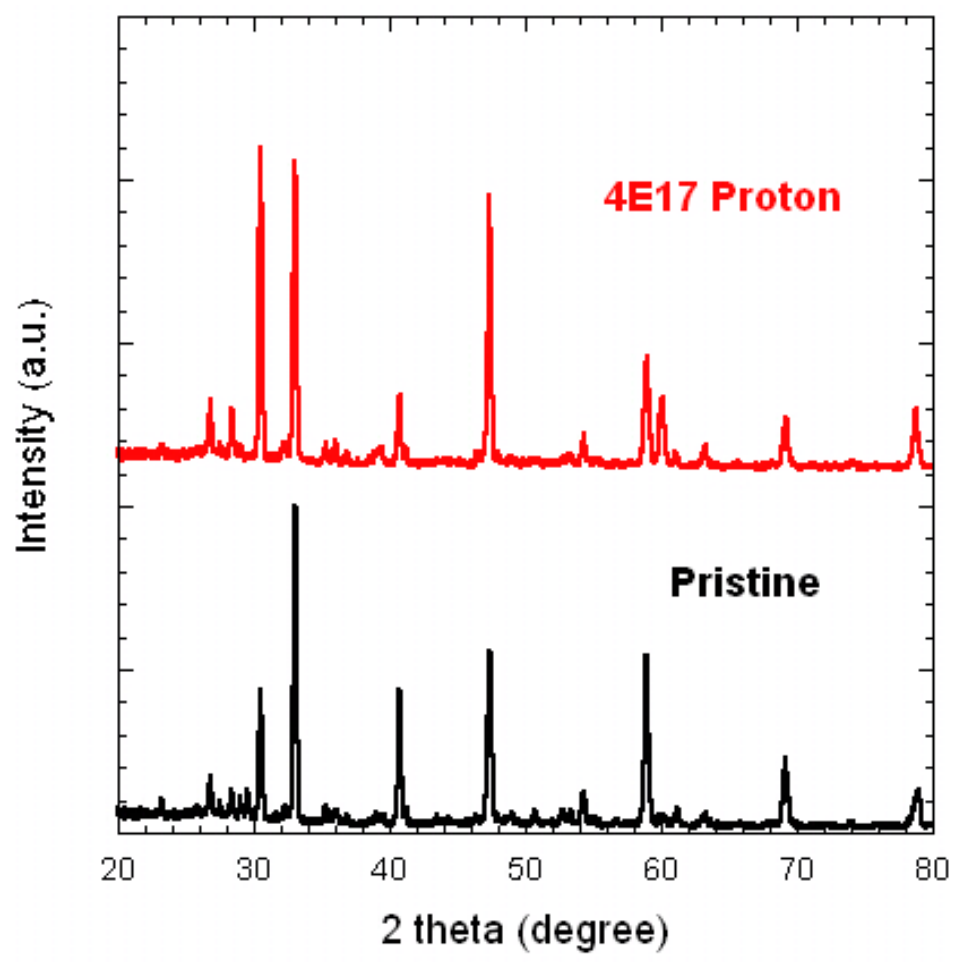

Figure 3-13. XRD Patterns for Composition CSLNTM-06 Prior to (Pristine) and After 2 MeV proton irradiation at a fluence of $4 \times 10^{17}$ ions $/ \mathrm{cm}^{2}$ (equivalent to a dose of $3 \times 10^{9} \mathrm{~Gy}$ ).

LANL performed a series of in situ electron irradiations using $300-\mathrm{keV}$ electrons generated in a Tecnai F30 TEM. By focusing electrons in the TEM on certain crystalline phases of the waste forms, it was possible to simulate radiolysis effects that might be experienced by potential CS/LN/TM High Mo titanate crystalline ceramic waste forms. Figure 3-14 shows the impact of electron irradiation simulating beta decay of a CSLNTM-06 melt and crystallized sample. The selected area electron diffraction images indicate the phase examined was a perovskite $(\mathrm{Ba}, \mathrm{Sr}, \mathrm{Ca}) \mathrm{TiO}_{3}$ phase, and that the crystalline nature of this phase was not impacted after 5 minutes of electron irradiation (equivalent to a dose level of $10^{10} \mathrm{~Gy}$ ). 


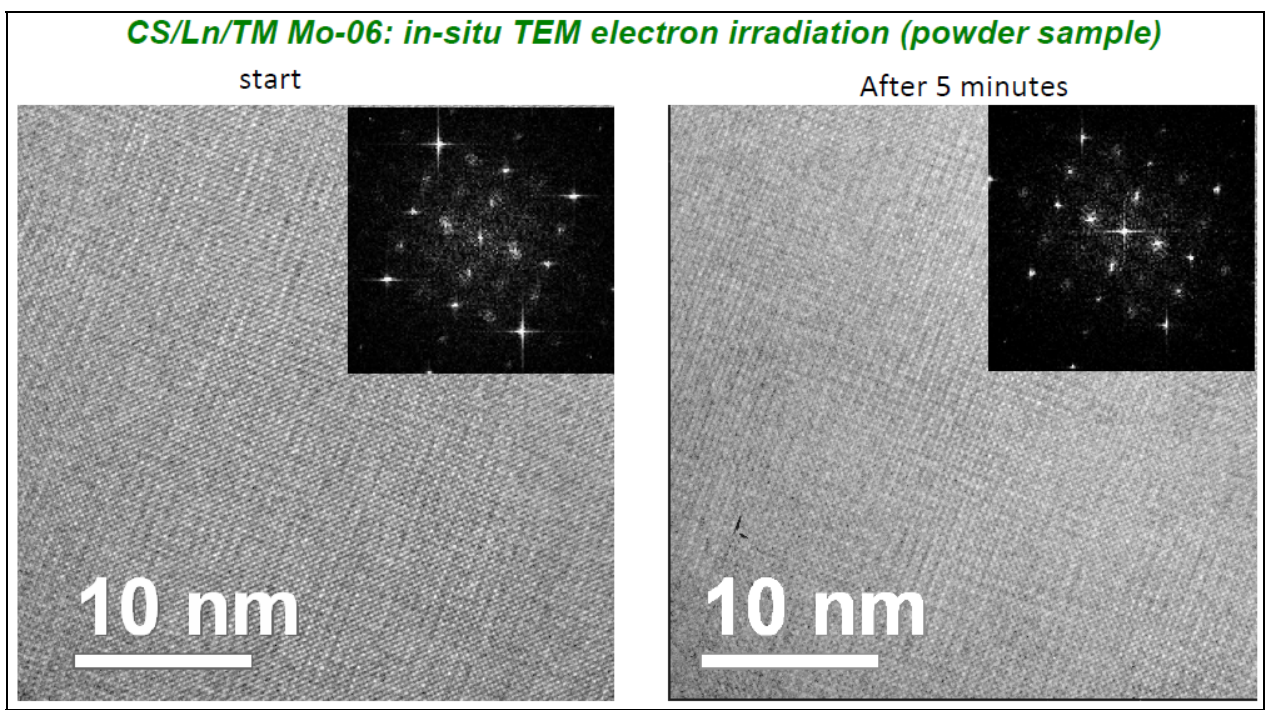

Figure 3-14. High-Resolution TEM Images Reveal Little Change to the Crystalline Structure of the Perovskite Phase Following Electron Irradiation at the Level of $10^{10} \mathrm{~Gy}$.

Figure 3-15 shows the results of an electron irradiation study for single phase powellite $\left(\mathrm{CaMoO}_{4}\right)$ samples. The results suggest that this material exhibits stability to 1000 years at anticipated selfirradiation doses $\left(2 \times 10^{10}-2 \times 10^{11} \mathrm{~Gy}\right)$, but that its stability may be rate dependent, which may therefore limit the activity of the waste for which it can be employed. Overall, these preliminary results indicate good radiation damage tolerance for the crystalline ceramic materials. 


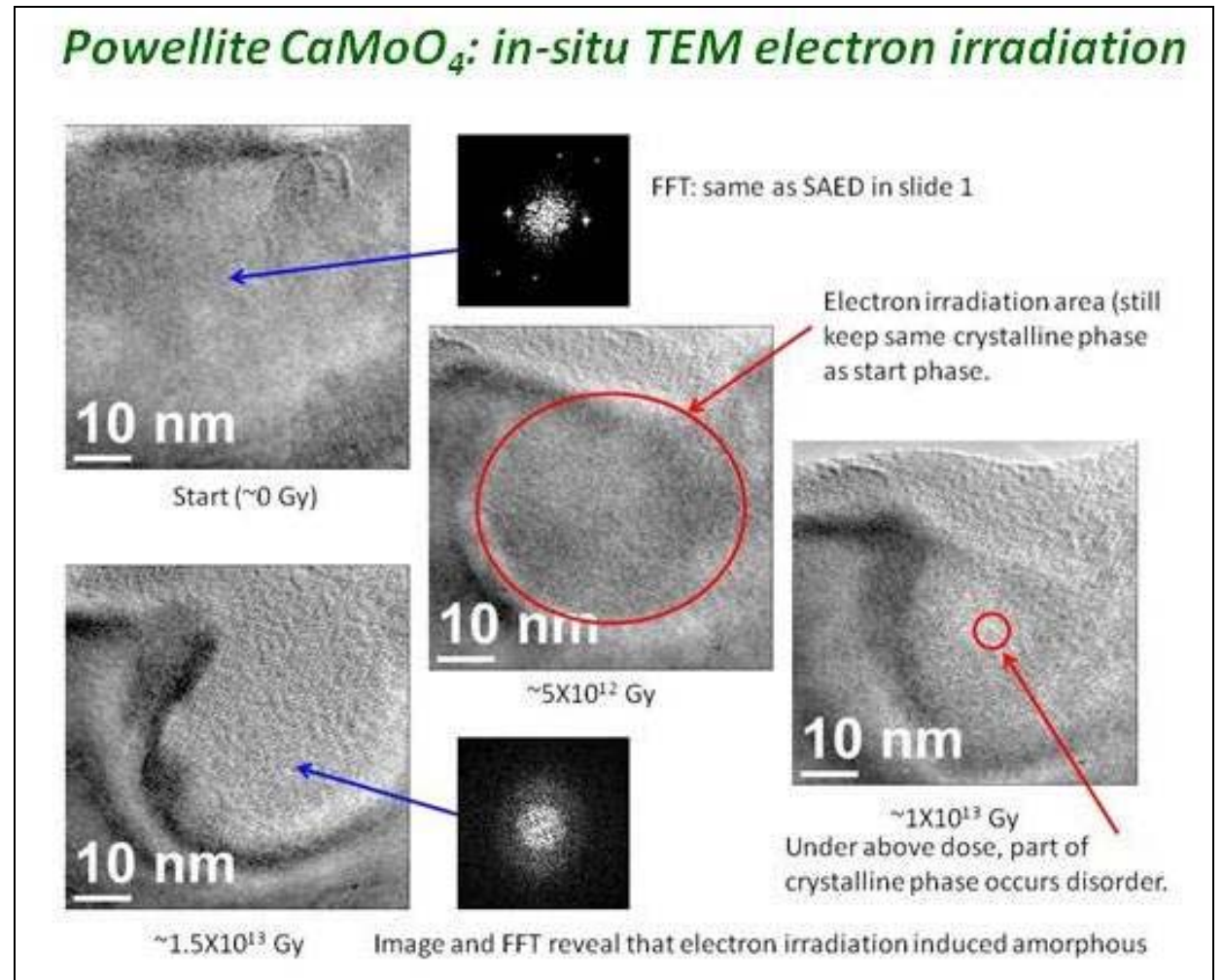

Figure 3-15. High-Resolution TEM Images Show the Microstructural Evolution of a $\mathrm{CaMoO}_{4}$ Sample Under Electron Irradiation at Increasing Doses. 


\section{SUMMARY AND CONCLUSIONS}

SRNL is developing crystalline ceramic waste forms to incorporate CS/LN/TM high Mo waste streams consisting of perovskite, hollandite, pyrochlore, zirconolite, and powellite phase assemblages. Simple raw materials, including $\mathrm{Al}_{2} \mathrm{O}_{3}, \mathrm{CaO}$, and $\mathrm{TiO}_{2}$ were combined with simulated waste components to produce multiphase crystalline ceramics. Fiscal Year 2011 activities included i) expanding the compositional range by varying waste loading and fabrication of compositions rich in $\mathrm{TiO}_{2}$, ii) exploring the processing parameters of ceramics produced by the melt and crystallize process, iii) synthesis and characterization of select individual phases of powellite and hollandite that are the target hosts for radionuclides of Mo, Cs, and $\mathrm{Rb}$, and iv) evaluating the durability and radiation stability of single and multi-phase ceramic waste forms.

Two fabrication methods, including melting and crystallizing, and pressing and sintering, were used with the intent of studying phase evolution under various sintering conditions. An analysis of the XRD and SEM/EDS results indicates that the targeted crystalline phases of the FY11 compositions consisting of pyrochlore, perovskite, hollandite, zirconolite, and powellite were formed by both press and sinter and melt and crystallize processing methods. Although many of the phases formed were similar across the wide compositional range studied in both FY10 and FY11, there were some important differences including the formation of an aluminum titanate phase. Several $\mathrm{Al}_{2} \mathrm{O}_{3}$ rich compositions did not show evidence of hollandite peaks and did not show a strong association of Cs with any other element by SEM/EDS analysis. Therefore, it currently appears that Cs is incorporated into different crystalline phases depending on the composition of the waste forms fabricated by the melt and crystallize process employed in this study. An evaluation of crystalline phase formation versus melt processing conditions revealed that hollandite, perovskite, zirconolite, and residual $\mathrm{TiO}_{2}$ phases formed regardless of cooling rate, demonstrating the robust nature of this process for crystalline phase development.

The results of this study indicate that pressureless sintering of oxides in air at temperatures near $1000{ }^{\circ} \mathrm{C}$ is insufficient for hollandite phase formation; however, elevated temperatures near the melting point of $1500{ }^{\circ} \mathrm{C}$ produced samples with a large amount of the hollandite $\left(\mathrm{BaAl}_{2} \mathrm{Ti}_{6} \mathrm{O}_{16}\right)$ phase. XRD and TEM analyses of the powellite phase indicated that $\mathrm{BaMoO}_{4}$ and $\mathrm{CaMoO}_{4}$ were readily formed by both the press and sinter and the melt and crystallize processing methods.

The multiphase ceramic composition CSLNTM-06 demonstrated good resistance to proton beam irradiation. Electron irradiation studies on $\mathrm{CaMoO}_{4}$ suggested that this material exhibits stability to 1000 years at anticipated self-irradiation doses $\left(2 \times 10^{10}-2 \times 10^{11} \mathrm{~Gy}\right)$, but that its stability may be rate dependent, therefore limiting the activity of the waste for which it can be employed. Overall, these preliminary results indicate good radiation damage tolerance for the crystalline ceramic materials.

The PCT results showed that the normalized release values for most of the elements measured, including all of the lanthanides and noble metals, were either very small or below the instrument detection limits. Elevated normalized release values were measured only for Cs, Mo, and Rb. It is difficult to draw further conclusions from these data until a benchmark material is developed for the PCT with this type of waste form. The variable release rates of Cs, Mo, and Rb may be tied to both the elemental composition of single phases as well as the overall phase assemblage. Calcination of the batch material prior to melting and crystallizing did not improve the chemical durability for Cs, Mo, and Rb as compared to the sample melted and crystallized without the calcination step. The calcined, simulated CS/LN/TM High Mo waste without additives had relatively low normalized release values for Cs, Mo, and Rb. A review of the chemical composition data for this sample showed that these elements were well retained after the calcination. Therefore, it will be useful to further characterize the calcined material to determine what form these elements are in after calcining. This, along with single phase studies on Cs containing crystal 
Preliminary Study of Ceramics for Immobilization of Advanced Fuel Cycle Reprocessing Wastes

structures such as hollandite, should provide insight into the best phases to incorporate these elements to produce a durable waste form. 


\section{FUTURE WORK}

Fiscal Year 2012 activities for this study will include: i) development of a reference crystalline ceramic composition and melt process for combined CS/LN/TM high Mo waste streams based on analysis of single phase synthesis and characterization accomplished in FY11, ii) characterization of the reference ceramic waste form in terms of durability via the PCT conducted at SRNL and radiation damage tolerance in collaboration and performed at LANL, and iii) investigation of process parameters including viscosity of melts, and retention of volatile components under simulated melter conditions to support potential melter testing of crystalline ceramic waste forms in FY13. 


\section{REFERENCES}

1. Gombert, D., S. Piet, T. Trickel, J. Carter, J. D. Vienna and W. Ebert, "Combined Waste Form Cost Trade Study," U.S. Department of Energy Report GNEP-SYSA-PMO-MI-DV-2009-000003, Idaho National Laboratory, (2008).

2. Crum, J. V., A. L. Billings, J. Lang, J. C. Marra, C. Rodriguez, J. V. Ryan and J. D. Vienna, "Baseline Glass Development for Combined Fission Products Waste Streams," U.S. Department of Energy Report AFCI-WAST-WAST-MI-DV-2009-000075, Pacific Northwest National Laboratory, (2009).

3. Billings, A. L., K. S. Brinkman, K. M. Fox, J. C. Marra, M. Tang and K. E. Sickafus, "Preliminary Study of Ceramics for Immobilization of Advanced Fuel Cycle Reprocessing Wastes," U.S. Department of Energy Report FCRD-WAST-2010-000158, SRNL-STI-2010-00560, Savannah River National Laboratory, Aiken, SC (2010).

4. Ringwood, A. E., E. S. Kesson, N. G. Ware, W. Hibberson and A. Major, “Geological Immobilisation of Nuclear Reactor Wastes,” Nature, 278219 (1979).

5. Ringwood, A. E., E. S. Kesson, K. D. Reeve, D. M. Levins and E. J. Ramm, “Synroc,” pp. 233-334 in Radioactive Waste Forms for the Future, W. Lutze and R. C. Ewing, eds. Elsevier, North-Holland, Amsterdam, Netherlands (1988).

6. Perera, D. S., B. D. Begg, E. R. Vance and M. W. A. Stewart, "Application of Crystal Chemistry in the Development of Radioactive Wasteforms," Advances in Technology of Materials and Materials Processing, 6 [2] 214-217 (2004).

7. Stefanovsky, S. V., A. G. Ptashkin, O. A. Knyazev, S. A. Dmitriev, S. V. Yudintsev and B. S. Nikonov, "Inductive Cold Crucible Melting of Actinide-bearing Murataite-based Ceramics," Journal of Alloys and Compounds, 444-445 438-442 (2007).

8. Demine, A. V., N. V. Krylova, P. P. Polyektov, I. N. Shestoperov, T. V. Smelova, V. F. Gorn and G. M. Medvedev, "High Level Waste Solidification Using a Cold Crucible Induction Melter”; pp. 27-34 in Mater. Res. Soc. Symp. Proc., Vol. 663, Scientific Basis for Nuclear Waste Management XXIV. Edited by K. P. Hart and G. R. Lumpkin. Warrendale, PA, 2001.

9. Advocat, T., G. Leturcq, J. Lacombe, G. Berger, R. A. Day, K. Hart, E. Vernaz and A. Bonnetier, "Alteration of Cold Crucible Melter Titanate-based Ceramics: Comparison with Hot-Pressed Titanatebased Ceramic”; pp. 355-362 in Mater. Res. Soc. Symp. Proc., Vol. 465, Scientific Basis for Nuclear Waste Management XX. Edited by W. J. Gray and I. R. Triay. Pittsburgh, PA, 1997.

10. Leturcq, G., T. Advocat, K. Hart, G. Berger, J. Lacombe and A. Bonnetier, "Solubility Study of Ti Zr-based Ceramics Designed to Immobilize Long-lived Radionuclides,” American Mineralogist, 86 [7-8] 871-880 (2001).

11. Biagioni, C., P. Orlandi and M. Pasero, “Ankangite from the Monte Arsiccio mine (Apuan Alps, Tuscany, Italy): occurrence, crystal structure, and classification problems in cryptomelane group minerals," Periodico Di Mineralogia, 78 [2] 3-11 (2009).

12. Cheary, R. W. and J. Kwiatkowska, "AN X-RAY STRUCTURAL-ANALYSIS OF CESIUM SUBSTITUTION IN THE BARIUM HOLLANDITE PHASE OF SYNROC,” Journal of Nuclear Materials, 125 [2] 236-243 (1984). 
13. Bosbach, D., T. Rabung, F. Brandt and T. Fanghanel, "Trivalent actinide coprecipitation with powellite (CaMoO4): Secondary solid solution formation during HLW borosilicate-glass dissolution,” Radiochimica Acta, 92 [9-11] 639-643 (2004).

14. Collins, E., "Testing Results CETE, Waste Forms - TMFP Composition Video Conference," (November 19, 2008).

15. Bakel, A. J., D. L. Bowers, K. J. Quigley, M. C. Regalbuto, J. A. Stillman and G. F. Vandegrift, "Dissolution of Irradiated Nuclear Fuel from the Big Rock Point Reactor"; pp. 71-88 in ACS Symposium Series, Vol. 933, Separations for The Nuclear Fuel Cycle in the 21st Century. Edited by G. J. Lumetta, K. L. Nash, S. B. Clark and J. I. Friese. American Chemical Society, Washington, DC, 2006.

16. Carter, M. L., E. R. Vance, D. R. G. Mitchell, J. V. Hanna, Z. Zhang and E. Loi, "Fabrication, characterization, and leach testing of hollandite, (Ba,Cs)(Al,Ti)(2)Ti6O16," Journal of Materials Research, 17 [10] 2578-2589 (2002).

17. Kesson, S. E., “THE IMMOBILIZATION OF CESIUM IN SYNROC HOLLANDITE,” Radioactive Waste Management and Environmental Restoration, 4 [1] 53-72 (1983).

18. Aubin-Chevaldonnet, V., D. Caurant, A. Dannoux, D. Gourier, T. Charpentier, L. Mazerolles and T. Advocat, "Preparation and characterization of $(\mathrm{Ba}, \mathrm{Cs})(\mathrm{M}, \mathrm{Ti})(8) \mathrm{O}-16(\mathrm{M}=\mathrm{Al} 3+, \mathrm{Fe} 3+, \mathrm{Ga} 3+, \mathrm{Cr} 3+$, Sc3+, Mg2+) hollandite ceramics developed for radioactive cesium immmobilization," Journal of Nuclear Materials, 366 [1-2] 137-160 (2007).

19. Jantzen, C. M., N. E. Bibler, D. C. Beam, C. L. Crawford and M. A. Pickett, "Characterization of the Defense Waste Processing Facility (DWPF) Environmental Assessment (EA) Glass Standard Reference Material," U.S. Department of Energy Report WSRC-TR-92-346, Revision 1, Westinghouse Savannah River Company, Aiken, SC (1993).

20. Jantzen, C. M., J. B. Picket, K. G. Brown, T. B. Edwards and D. C. Beam, "Process/Product Models for the Defense Waste Processing Facility (DWPF): Part I. Predicting Glass Durability from Composition Using a Thermodynamic Hydration Energy Reaction Model (THERMO)," U.S. Department of Energy Report WSRC-TR-93-672, Revision 1, Westinghouse Savannah River Company, Aiken, SC (1995). 